\title{
NEGOTIATING THE ETERNAL: THE PARADOX OF ENTRENCHING SECULARISM IN CONSTITUTIONS
}

\author{
Yaniv Roznai ${ }^{*}$
}

2017 MICH. ST. L. REV. 253

\begin{abstract}
"Our first business is to supervise the production of stories, and choose only those we think are suitable."

(Plato, The Republic)

"Time is the moving image of eternity."

(Plato, Timaeus)
\end{abstract}

\section{TABLE OF CONTENTS}

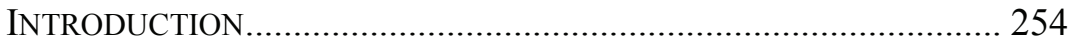

I. SECULARISM AS AN ETERNAL CONSTITUTIONAL PRINCIPLE.. 258

A. Secularism as an Explicit Eternal Principle .................... 258

B. Secularism as an Implicit Eternal Principle .................... 263

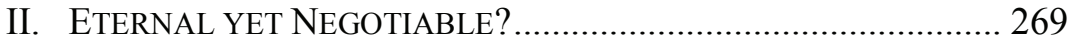

A. Three Case Studies ........................................................ 270

1. Turkey .................................................................... 270

* Associate Professor, Radzyner Law School, The Interdisciplinary Center Herzliya (IDC). LL.B., B.A., Government, IDC (2006); LL.M., The London School of Economics and Political Science (LSE) (2009); Ph.D., LSE (2014). Email: Yaniv.roznai@idc.ac.il. An earlier version of this Article was presented at the AALS 111th Annual Meeting, Section on Law and Religion Panel on "Is Secularism a Non-Negotiable Aspect of Liberal Constitutionalism?" (San Francisco, January 4, 2017). I would like to thank the panel's participants: Alan Brownstein, Tarunabh Khaitan, Jaclyn L. Neo, Frank S. Ravitch, and Seval Yildirim for a fantastic debate that has surely improved this Article. Special thanks to Richard Albert, the panel's chair, for elaborated remarks on an earlier version. This study was also presented at the Radzyner Law School, IDC staff seminar (April 25, 2017). I thank the participants for their remarks, and especially Aharon Barak, Lior Barshack, Amnon Lehavi, Ronit Levine-Schnur, Sharon Rabin-Margalioth, Adam Shinar, and Lorenzo Zucca. I would also like to extend my gratitude to Eoin Daly, Pietro Faraguna, Hanna Lerner, Nadiv Mordechay, Michele Romano, Ioanna Tourkochoriti, and Serkan Yolcu for assistance with sources and useful remarks, and Gal Barir for an excellent research assistance. I thank the editorial staff of the Michigan State Law Review, and especially Angela Caulley and Kirstin Tiffany, for their hard work. In light of the fallibility of human nature, as emphasized in this Article, errors are inevitable, and I take the sole responsibility for any of these. 


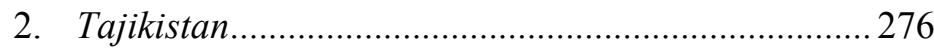

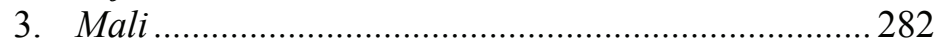

B. On the Negotiability of "Eternal" Principles ...................290

1. Non-self-entrenched Eternity Clauses.......................290

2. Fifty Shades of Secularism .......................................295

3. Volksgeist and Constitutional Unamendability ......... 301

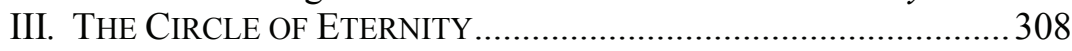

A. Lex Temporalis \& Lex Aeterna: Eternity in Religious

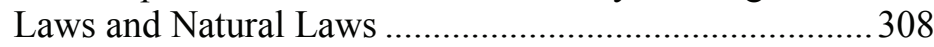

B. Secularism and the Age of Rationalization.......................316

C. The Paradox of Modern Constitutional Eternity............... 321

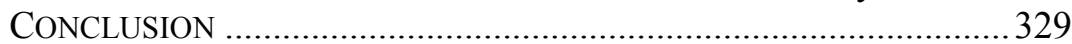

\section{INTRODUCTION}

This Article focuses on the following question: Is Secularism a Non-Negotiable Principle? The place of secularism, or alternatively of religion, in society and within the constitutional order has certainly been a central topic for the study of constitutionalism. ${ }^{1}$ I approach the question from a different and narrower perspective; that of "constitutional unamendability." The term constitutional unamendability refers to the resistance of certain constitutional principles to their amendment or revision through formal constitutional amendments. ${ }^{2}$

In many states, national constitutions entrench constitutional principles in a way that restricts or prohibits any amendment to them. Nowadays, such constitutional protection is even enforced in some states through substantive constitutional review of constitutional amendments in order to ensure that the amendment power does not

1. See generally Richard Albert, American Separationism and Liberal Democracy: The Establishment Clause in Historical and Comparative Perspective, 88 Marquette L. ReV. 867 (2005). For various studies and perspectives, see Symposium, Constitutionalism and Secularism in an Age of Religious Revival: The Challenge of Global and Local Fundamentalisms, 30 CARDOZO L. REV. 2331 (2009).

2. See Richard Albert, Constructive Unamendability in Canada and the United States, 67 SuP. CT. L. REV. 181, 182-90 (2014). There has been an increasing volume of literature on constitutional unamendability lately. See, e.g., id.; George Mader, Binding Authority: Unamendability in the United States Constitution-A Textual and Historical Analysis, 99 MARQ. L. REV. 841 (2016); AN

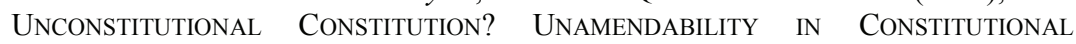
Democracies (Richard Albert \& Bertil Emrah Oder eds., forthcoming 2018). 
exceed its limits. ${ }^{3}$ Perhaps the most famous example of constitutional unamendability is Article 79(3) of the German Basic Law (Grundgesetz) of 1949. Written against the background of the experience of the Weimar Constitution and the Holocaust, Article 79(3) prohibits constitutional amendments affecting the division of the Federation into states (Länder), human dignity, the constitutional order, and basic institutional principles describing Germany as a democratic and social federal state. ${ }^{4}$ This provision is commonly referred to as "the Eternity Clause" (die Ewigkeitsklausel), and following the German jargon, the terminology of "eternity" to describe such protected provisions spread in the constitutional

3. See, e.g., Kemal GöZler, Judicial Review of Constitutional AmENDMENTS: A COMPARATIVE STUdY (2008); Aharon Barak, Unconstitutional Constitutional Amendments, 44 IsR. L. REV. 321 (2011); Carlos Bernal, Unconstitutional Constitutional Amendments in the Case Study of Colombia: An Analysis of the Justification and Meaning of the Constitutional Replacement Doctrine, 11 InT'L J. Const. L. 339 (2013); Gábor Halmai, Judicial Review of Constitutional Amendments and New Constitutions in Comparative Perspective, 50 WAKe Forest L. ReV. 951 (2015); Gábor Halmai, Unconstitutional Constitutional Amendments: Constitutional Courts as Guardians of the Constitution?, 19 Constellations 182 (2012); Gary Jeffrey Jacobsohn, An Unconstitutional Constitution? A Comparative Perspective, 4 InT'L J. Const. L. 460 (2006); Rory O'Connell, Guardians of the Constitution: Unconstitutional Constitutional Norms, 4 J. Civ. Liberties 48 (1999); Yaniv Roznai, Unconstitutional Constitutional Amendments-The Migration and Success of a Constitutional Idea, 61 Ам. J. CoмP. L. 657 (2013); Po Jen Yap, The Conundrum of Unconstitutional Constitutional Amendments, 4 Global Constitutionalism 114 (2015).

4. See Helmut Goerlich, Concept of Special Protection for Certain Elements and Principles of the Constitution Against Amendments and Article 79(3), Basic Law of Germany, 1 NUJS L. ReV. 397, 398 (2008); Ulrich K. Preuss, The Implications of "Eternity Clauses": The German Experience, 44 IsR. L. REV. 429, 440 (2011). 
literature. ${ }^{5}$ Others have described such provisions as an "absolute rigidity," "indefinite entrenchment," or "unamendable provisions."

The concept of "eternity" has been explored widely already in medieval philosophy; mainly since infinity and supra-temporality notions were regularly ascribed to God. ${ }^{9}$ On later periods, even referring to the constitution - the fundamental law of the land - as having an eternal character is also not unheard of. When John Locke wrote " The Fundamental Constitution' of the colony of Carolina in 1669 ," he stipulated that it "shall be and remain the sacred and unalterable form and rule of government of Carolina forever." 10 I have elsewhere written that such a treatment of the entire constitutional document as unamendable may derive either from the drafters of the constitution being exceptionally arrogant in the belief that they have achieved the apex of perfection or from assigning the document to a super-human or divine source. ${ }^{11}$ It is precisely the latter alternative that is so striking when one thinks of the constitutional entrenchment of secularism. Secularism rejects notions of a divine authority, yet at the same time, the designation of

5. See, e.g., Christoph Bezemek, Constitutional Core(s): Amendments, Entrenchments, Eternities and Beyond Prolegomena to a Theory of Normative Volatility, 11 J. JuRIS. 517 (2011); Andrew Friedman, Dead Hand Constitutionalism: The Danger of Eternity Clauses in New Democracies, 4 Mexican L. Rev. 77 (2011); Silvia Suteu, Eternity Clauses in Post-Conflict and Post-Authoritarian Constitution-Making: Promise and Limits, 6(1) GlOBAL Constitutionalism 63 (2017); Ladislav Vyhnánek, The Eternity Clause in the Czech Constitution as Limit to European Integration-Much Ado About Nothing?, 9 VienNa J. InT'L CONST. L. 240 (2015); Sharon Weintal, The Challenge of Reconciling Constitutional Eternity Clauses with Popular Sovereignty: Toward Three-Track Democracy in Israel as a Universal Holistic Constitutional System and Theory, 44 IsR. L. REV. 449 (2011).

6. Dag Anckar, Notes on Constitutional Endurance, 5 BeIJING L. REV. 80, 86 (2014).

7. Richard Albert, Constitutional Handcuffs, 42 ARIZ. ST. L.J. 663, 672, 678 n.42 (2010) (mentioning there also "absolute entrenchment").

8. Yaniv Roznai, Unamendability and the Genetic Code of the Constitution, 27 Eur. Rev. PuB. L. 775 (2015).

9. For an excellent exploration of eternity in Medieval Philosophy, see Taneli Kukkonen, Eternity, in The Oxford Handbook of Medieval Philosophy 525 (John Marenbon ed., 2012). For an elaboration on the conceptualization of time in antiquity, see Richard SorABJi, TIME, CREATION AND THE CONTINUUM: THEORIES in ANTiQuity AND the EARly Middle Ages (1983).

10. JOHN LOCKE, THE WORKS OF JOHN LOCKE 198 (12th ed.1824).

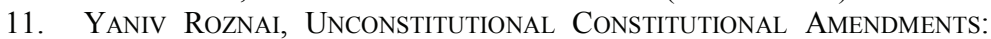
The Limits of Amendment Powers 16 (2017). A similar point is made by Levinson. Sanford Levinson, The Political Implications of Amending Clauses, 13 Const. Comm. 107, 112-13 (1996). 
secularism as an eternal principle itself abandons the idea of a secular law - changeable by nature - shifting to the realms of the transcendent.

This Article seeks to study the eternal protection of the principle of secularism in national constitutions. Now, as the sharp reader noticed, in the opening paragraph, I did not ask whether secularism ought to be a non-negotiable principle, but rather whether it $i$ s one. In other words, this is not a normative inquiry. The aim of this Article is therefore fairly modest; I wish to examine actual existing constitutional arrangements that prima facie provide secularism an absolute protection from change in the constitution, in an attempt to identify and explain the character of these existing constitutional arrangements. Thus, this is another attempt to understand constitutionalism as a form of political practice, and to evaluate how this practice works against its own logic. ${ }^{12}$

Part I of this Article discusses secularism as an Eternal Constitutional Principle. It reviews various constitutions that entrench secularism as an implicit or explicit principle. Part II explains why constitutional eternity should not be regarded as if the protected constitutional principles are non-negotiable. This is demonstrated through three case studies that focus on Turkey, Tajikistan, and Mali. Against the backdrop of these case studies, I argue that eternal principles should be regarded as negotiable on three main grounds. First, as long as eternity clauses are not selfentrenched, they can be formally amended. Second, what is protected by the eternity clauses is a constitutional principle-secularism rather than a rule. In light of its elastic meaning, the principle of secularism can therefore be reshaped and reinterpreted with time. Third, when the values protected by constitutional unamendability conflict with the community spirit or the Volksgeist, even the mechanism of constitutional eternity would not be able to hinder the true forces in society that demand change. Part III addresses what I term "the Circle of Eternity." It demonstrates the central place of eternity in religious laws and natural law, an element that distinguishes them from secular law. It then describes the secular developments in the age of rationalization in order to finally reveal the self-contradiction of modern constitutional eternity. On the one

12. Other scholars have taken a similar approach. $C f$. Martin Loughlin, Constitutional Theory: A 25th Anniversary Essay, in 25 Oxford J. Legal Stud. 183, 186 (2005); Stephen Tierney, Constitutional Referendums: The Theory and Practice of Republican Deliberation 2 (2012). 
hand, the basic fundamentals of modern constitutionalism are secular, from the standing point of popular sovereignty and people's rational ability to decide their faith, destiny, and consequently, to design their constitutional order. Yet, at the same time, this very presupposition rests as an unalterable pillar - an absolute truth that is the constitutional eternity.

\section{SECULARISM AS AN ETERnAl CONSTITUTIONAL PRINCIPLE}

This Part studies the absolute constitutional entrenchment of the principle of secularism in constitutions. It first reviews constitutions in which secularism is explicitly protected as an unamendable or eternal principle; i.e., as a constitutional principle that is expressly shielded from formal constitutional amendments. It then continues to review constitutional systems in which courts have declared the principle of secularism to be implicitly protected from amendments, focusing on India and Italy.

\section{A. Secularism as an Explicit Eternal Principle}

Historically, there is a strong link between constitutional eternity and notions of secularism, as the early modern examples of constitutional unamendability protected separation between state and church. This occurred first in North America in the eighteenth century. The 1776 Constitution of New Jersey specified in Article 23 that members of the Legislative Council or House of Assembly had to take an oath not to "annul or repeal" the articles opposing church establishment and conferring equal civil rights on all Protestants. ${ }^{13}$ Likewise, the Delaware Constitution of 1776 prohibited in Article 30 amendments to the prohibition on establishing any one religious sect. ${ }^{14}$

Of course, many states declare or define themselves as "secular" or protect in their constitutions the separation between the

13. N.J. CONST. art. XXIII.

14. Del. Const. art. XXIX. This Article provides:

There shall be no establishment of any one religious sect in this State in preference to another; and no clergyman or preacher of the gospel, of any denomination, shall be capable of holding any civil office in this State, or of being a member of either of the branches of the legislature, while they continue in the exercise of the pastoral function.

Id. 
state and religious institutions. ${ }^{15}$ However, some modern constitutions have taken this constitutional protection to its extreme and, like the early examples of New Jersey and Delaware, provide the "secular" nature of the state or the principle of "separation between the state and churches" an absolute entrenchment in the constitution, protecting them from possible amendments or revisions. ${ }^{16}$ These states elevate these enshrined principles above ordinary and even constitutional politics, designating them as principles that cannot be amended or abolished; they are beyond the reach of the constitutional amendment power.

The Constitution of Portugal of 1976, for example, states in Article 288(c) that "[t]he laws revising the Constitution [must] safeguard . . . The separation between church and State." ${ }^{17}$ Likewise, the 2013 Constitution of the Central African Republic expressly excluded in Article 101 from revisions the republican and secular state form. ${ }^{18}$ Such a supreme constitutional protection appears also in Angola, ${ }^{19}$ Burundi, ${ }^{20}$ Chad,${ }^{21}$ the Republic of Congo, ${ }^{22}$ Côte d'Ivoire, ${ }^{23}$ Guinea, ${ }^{24}$ Mali, ${ }^{25}$ São Tomé and Príncipe, ${ }^{26}$ Tajikistan, ${ }^{27}$

15. See, e.g., Konstitutsila Rossiskoi Federatsil [Konst. RF] [CONSTITUTION] art. 14 (Russ.) ("The Russian Federation shall be a secular state. No religion may be instituted as state-sponsored or mandatory religion. Religious associations shall be separated from the State and are equal before the law."); Magyarország Alaptörvénye [The Fundamental LaW of Hungary], ALAPTÖRVÉNY ("The State and Churches shall be separate. Churches shall be autonomous."); CONSTITUTION OF Kosovo, art. VIII (2008) ("The Republic of Kosovo is a secular state and is neutral in matters of religious beliefs."); CONSTITUTION OF LATVIA, art. XCIX (1922) ("The church shall be separate from the State.").

16. See supra notes 13-14 and accompanying text.

17. Constitution of Portugal 1976, art. 288(c).

18. Constitution of Central African Republic 2013, art. 101.

19. Constitution of ANGOLA, art. 236(g) (2010) ("The secular nature of the state and the principle of the separation of church and state.").

20. CONSTITUTION OF BURUNDI, art. 299 (2005) ("No procedure of revision may be retained if it infringes the national unity, the cohesion of Burundian People, the secularity of the State, the reconciliation, the democracy or the integrity of the territory of the Republic.").

21. CONSTITUTION OF CHAD, art. 223 (1996) ("No procedure of revision may be engaged or pursued when it infringes . . the republican form of the State, the principle of the separation of powers and secularity ....").

22. Constitution of THE Republic of CONGO, art. 240 (2015) ("No procedure of revision may be engaged or pursued in [an] interim period or when it infringes the integrity of the territory. The republican form, and the secular character of the State may not be made the object of revision.").

23. CONSTitution OF CÔTE D'IvOIRe 2000, art. 127 ("No procedure of revision may be undertaken or pursued if it infringes on the integrity of the territory. 
Togo, ${ }^{28}$ and Turkey. ${ }^{29}$ This unamendability protection is therefore a central feature of constitutional design that demands scholarly attention.

It appears evident from the above list that many African states that include this "eternal protection" are former French colonies. ${ }^{30}$ It is indeed interesting to point to the relationship between colonialism and religions, especially Islam. A recent study demonstrates that no country in the French colonial tradition has adopted a constitutional repugnancy clause, according to which all laws repugnant to Islam are void. ${ }^{31}$ In contrast, countries that were colonized by the British have a relatively high degree of constitutional Islamization. It therefore appears that by including this unamendability, they aim to follow laïcité - the French concept of secularism. ${ }^{32}$

The republican form and the secular [form] of the State may not be made the object of a revision.").

24. Constitution of Guinea 2010, art. 154 ("The republican form of the State, the principle of secularity, the principle of the uniqueness of the State, the principle of the separation and of the equilibrium of the powers, the political and syndical pluralism, [and] the number and the duration of the mandates of the President of the Republic[,] may not be made the object of a revision.").

25. Constitution of MALi 1992, art. 118 ("No procedure of revision can be initiated or pursued when it infringes the integrity of the territory. The republican form and the secularity of the State as well as [regime of] plural-parties cannot be the object of revision.").

26. Constitution OF São Tomé And PrínCIPe 1975, art. 154(b) (providing that "[t]he secular status of the State" is not subject to constitutional revision).

27. CONSTITUTION OF TAJiKistan 1994, art. 100 ("The republican form of government of, the territorial integrity of, and the democratic, rule of law, secular, and social natures of the state may not be changed.").

28. Constitution of TOGO 1992, art. 144 ("The Republican form and the secularity of the State may not be the object of revision.").

29. Constitution of the Republic of Turkey Oct. 18, 1982, art. 4 ("The provision of Article 1 regarding the form of the State being a Republic, the characteristics of the Republic in Article 2, and the provisions of Article 3 shall not be amended, nor shall their amendment be proposed."). According to Article 2, the Republic of Turkey is a secular state. See id. art. 2.

30. These are Togo, Mali, Guinea, Côte d'Ivoire, the Republic of Congo, Chad, and the Central African Republic. On the influence of colonial power on legal systems, see Daniel M. Klerman et al., Legal Origin or Colonial History?, 3 J. LEgAL ANALYSIS 379, 380 (2011).

31. See Dawood I. Ahmed \& Moamen Gouda, Measuring Constitutional Islamization: The Islamic Constitutions Index, 38 HASTINGS INT'L \& COMP. L. REV. 1, 55 (2015).

32. On the French notion of laïcité, see Jean-Paul Costa, La Conception Française De La Laïcité, 149 Revue Des Sciences Morales et Politiques 167 (1994) (Fr.) (describing the formation of laïcité in the 19th century as a reaction against the power of the Catholic Church and the dogma of papal infallibility, its 
Now, there is no doubt that in France, secularism is a fundamental and explicit constitutional principle. ${ }^{33}$ This raises an interesting question: Is laïcité an unamendable principle in France, like in the former French colonies mentioned above? The 1958 French Constitution includes an eternity clause, Article 89, according to which "[t]he republican form of government shall not be the object of any amendment." ${ }^{34}$ Therefore, it does not explicitly refer to secularism. Notwithstanding this absence, many view the principles of secularism as protected by Article 89 based upon the importance of laïcite to the French conception of republicanism. ${ }^{35}$ According to this approach, to generate allegiance to the republic and to maintain unity, the state must monitor religion and regulate the corporate organization of religious groups. ${ }^{36}$ Indeed, the principle of laïcité was interpreted by the Conseil Constitutionnel as precluding "the use of

development and the challenges to his concept posed by immigration and the increasing power of religions); Michel Troper, Sovereignty and Laïcité, 30 CARDOZO L. ReV. 2561, 2563 (2009). Troper states:

Laïcité cannot be completely defined by the usual idea of an absence of influence of religion on the State or, as it is sometimes said, by a separation between State and religion. But it can also be characterized as an attitude of the State towards religion, decided unilaterally by the State. Indeed, most authors, when defining laïcité, use other characters, such as freedom of religion, tolerance or neutrality. Thus, they characterize not a mutual attitude or the relationship between religion and the State, but only the attitude of the State towards religion, because even the decision not to interfere with religious matters is a sovereign decision.

Id.

33. See András Sajó, Constitutionalism and Secularism: The Need for Public Reason, 30 CARdozo L. Rev. 2401, 2404 (2009).

34. 1958 CONST. art. 89 (Fr.).

35. See, e.g., Philippe Ardant, La Laïcité-Introduction, 75 PouvoIrs, Revue Française D’études Constitutionnelles et Politiques 5, 5 (1995) (Fr.) (stating that secularism is one of the founding principles of the state, as a republican value); Alain Bergounioux, La Laïcité, Valeur de la République, 75 PouvoIrs, Revue Française D’études Constitutionnelles et Politiques 17, 17 (1995) (Fr.) (describing laïcité as a fundamental republican principle).

36. See generally Michel Troper, Republicanism and Freedom of Religion in France, in Religion, Secularism \& Constitutional Democracy 316 (Jean L. Cohen \& Cécile Laborde eds., 2016). As Eoin Daly explains, "laïcité, formalist equality and indivisibility all coalesce around a single republican doctrine, affirming the singularity of the French people, understood as an abstract and disembodied corpus of citizens whose juridical status is defined independently of their contingent characteristics, beliefs and origins." Eoin Daly, The Indivisibility of the French Republic as Political Theory and Constitutional Doctrine, 11 EUR. CONST. L. REV. 458, 476 (2015). 
religious beliefs as a criterion through which to gain exemption from rules governing the relationship between private individuals and public entities." ${ }^{37}$ According to the republican logic, the idea of religious communities releasing themselves from general and neutral legislation undermines citizenship and the indivisibility of the republic. ${ }^{38}$ A support for the claim that laïcite is included within the French unamendable provision one may find in Article 1 of the Constitution that states that "France shall be an indivisible, secular, democratic and social Republic." 39 Laïcité thus figures in the first article that describes what republicanism - which is unamendable on the basis of Article 89-means in France. Consequently, it is certainly plausible to argue that the principle of laïcite itself is unamendable. ${ }^{40}$ Certainly in public discourse, laïcité is understood as an integral part of republicanism.

On the other hand, there is a counter textual argument. Article 89(5) does not refer to republicanism as such, but rather to "the republican form of government" more narrowly. ${ }^{41}$ While this is certainly open to interpretation, arguably this form of government does not include Church-State relations. The Law Concerning the Separation of the Churches and the State, which established the secular character of the French state, banning state funding for religious activities and removing religious symbols from public

37. See Daly, supra note 36 (citing Conseil constitutionnel [CC] [Constitutional Court] decision No. 2004-505DC, Nov. 19, 2004 (Fr.)).

38. See Conseil constitutionnel [CC] [Constitutional Court] decision No. 2004-505DC, Nov. 19, 2004 (Fr.).

39. 1958 ConsT. art. 1 (Fr.).

40. Compare this to the early jurisprudence of the Turkish Constitutional Court and its broad interpretation of the unamendable provision. Article Nine of the 1961 Constitution stipulated that " $[\mathrm{t}]$ he provision of the Constitution establishing the form of the state as a republic shall not be amended nor shall any motion therefor be made." Constitution of the Republic of Turkey 1961, art. 9. The Turkish Constitutional Court has held that "what is deemed unamendable is not the word 'Republic', but the Republican regime with its characteristics as stipulated in the Constitution", thereby expanding the unamendable protection to the characteristics of the republic as stipulated in Article 2, such as "nationalistic, democratic, secular and social state governed by the rule of law, based on human rights." See Tarik Olcay, Unamendability of Amendable Clauses: The Case of the Turkish Constitution, in AN UNCONSTITUTIONAL CONSTITUTION? UNAMENDABILITY IN Constitutional Democracies, supra note 2 (citing Turkish Constitutional Court E. $1970 / 1,322)$.

41. 1958 CONST. art. 89 (Fr.). 
buildings, was only promulgated in $1905 .{ }^{42}$ Thus, until 1905 a "republic" coexisted with religious establishment.

When the "republican" form of government was designated as an unamendable principle in 1884, its original aim was to express a strong repudiation of Monarchism..$^{43}$ Of course, nowadays if one considers this protection of the "republican" form of government as narrowly meaning merely not a return to the monarchy, this would eventually amount to saying that there are no substantive limits on the amendment power in the constitution. ${ }^{44}$ In any event, nowadays the question is purely a discursive one, without real legal implications. This is because the Conseil Constitutionnel took a rather restrained position regarding the unamendability ${ }^{45}$ when it laconically declared in 2003 that it lacks any competence to conduct judicial review of constitutional amendments; i.e., to rule on the content of "republican form of government" as protected in Article $89(5) \cdot{ }^{46}$

\section{B. Secularism as an Implicit Eternal Principle}

The previous section described the constitutional phenomenon of states that provide an expressed constitutional protection from amendments to the principle of secularism or the separation between

42. See Loi Concernant la Séparation des Églises et de l'État, J. OfFICIEL De La République FrançAise, Dec. 11, 1905, 7205 (Fr.). For a brief review of the history of the relationship between state and church in France, see Ioanna Tourkochoriti, The Burka Ban: Divergent Approaches to Freedom of Religion in France and in the U.S.A., 20 WM. \& MARY BILL RTS. J. 791, 800-01 (2012).

43. On how constitution-drafters use unamendable provisions for expressing certain constitutional values and political commitments, see generally Richard Albert, The Expressive Function of Constitutional Amendment Rules, 59 MCGILL L.J. 225 (2013).

44. See RoznaI, supra note 11, at 213; Carl J. Friedrich, The New French Constitution in Political and Historical Perspective, 72 HARV. L. REV. 801, 812 (1959).

45. See Susan Wright, The Self-restraint of the French Conseil Constitutionnel in 2003 and 2004, 11 European PuB. L. 495, 495 (2005); Denis Baranger, The Language of Eternity: Judicial Review of the Amending Power in France (or the Absence Thereof), 44 IsR. L. REV. 389, 391 (2011).

46. Conseil constitutionnel [CC] [Constitutional Court] decision No. 2003469DC, Mar. 26, 2003 (Fr.). This is in contrast with an early decision in which the Conseil Constitutionnel specified that, subject to the temporal and substantive restrictions provided in the Constitution, the constituent power is sovereign. Conseil constitutionnel [CC] [Constitutional Court] decision No. 92-312DC, Sept. 2, 1992 (Fr.). From this statement, it was clear that the amendment power has to observe substantive unamendability imposed upon it by the Constitution. 
state and church. In these states, the constitution-maker, as holder of the constituent power, decides to shield secularism from possible revisions, as it is considered a central element within the constitutional order, an unalterable aspect of the constitutional identity. In some states, however, which do not include such explicit unamendable protection of secularism, courts have held that such an eternal protection derives implicitly from the constitution. This is the case, for example, of Italy and India.

Italy is a predominantly Catholic country, but simultaneously defines itself a secular state. In contrast to France, secularism is not explicitly proclaimed in the constitution rather it is deduced from the fundamental norms contained in the 1948 Republican Constitution. ${ }^{47}$ In a number of decisions, the Corte Costituzionale, which carries the ultimate competence to interpret the Constitution, affirmed the Italian state's secular character, as derived from a holistic reading of the Constitution's various provisions. ${ }^{48}$

The Italian principle of secularism-laicità,${ }^{49}$ as expounded by the Italian Constitutional Court, means protection and promotion of religious freedom within a pluralist regime of confessions and cultures. It is neither state's indifference toward religions, nor an instrument to block religious presence in the public sphere. Consequently, laicità refers to a mixture of values and responsibilities in a modern plural and democratic state, in which religion has an active role. In other words, laicità presumes an equally respect-worthy plurality of values in the area of religion and conscience, necessitates state neutrality regarding religious and nonreligious beliefs, and demands equal protection for both. ${ }^{50}$ For these reasons, Italian laicità is regarded as positive and active (laicità positiva)..$^{51}$

47. See Francesca Astengo, Freedom of Religion Crucified? Secularism and Italian Schools Before the European Court of Human Rights, 41 POLITIQUE EUROPÉENNE 12, 17 (2013).

48. Racc. uff. Corte Cost., decisions No. 203/1989; No. 259/1990; No. 13/1991; No. 195/1993; No. 421/1993; No. 334/1996; No. 329/1997; No. 508/2000; No. 327/2002 (It.). See also Astengo, supra note 47, at 12.

49. On the terminology of secularism in Italy, see Edoardo Tortarolo, How Do You Say 'Secular' in Italian?, in Making Sense of the Secular: Critical PERSPECTIVES FROM EuROPE TO AsIA 56-67 (Ranjan Ghosh ed., 2013).

50. Alessandro Ferrari \& Silvio Ferrari, Religion and the Secular State: The Italian Case, in Religion and the Secular State: Interim National Reports 431, 433 (Javier Martínez-Torrón \& W. Cole Durham, Jr. eds., 2010).

51. See id. at 432-33; see also Citizens' Rights and Constitutional Affairs: Practice and Observance in the EU Member States, EuR. PAR. DOC., 26 n.10 (2013) 
Italian laicità, as just described, was classified by the Italian Corte Costituzionale in decision number 203/1989 among the "supreme principles of constitutional order." 52 Why is this classification important? The labeling of laicità as one of the fundamental principles of the constitutional order allegedly means that it is located beyond the reach of the amendment power and that its revision would be subject to the control of the constitutional court. The Italian Constitution of 1947 includes an explicit eternity provision according to which "[t]he form of Republic shall not be a matter for constitutional amendment." ${ }^{53}$ Italian scholars suggested that in addition to this explicit protection, other fundamental principles such as democracy and inviolable rights are implicitly unamendable. ${ }^{54}$ The Italian Constitutional Court accepted this approach in its decision number 1146/1988, when it declared the following:

The Italian Constitution contains some supreme principles that cannot be subverted or modified in their essential content . . . . Such are principles that the Constitution itself explicitly contemplates as absolute limits to the power of constitutional revision, such as the republican form ... as well as principles that, although not expressly mentioned among those not subject

(UK), http://www.europarl.europa.eu/RegData/etudes/etudes/join/2013/474399/IPOLLIBE_ET(2013)474399_EN.pdf [https://perma.cc/VDS3-GFB8] (describing positive secularism in such a manner "that the principle implies non-indifference by the state with regard to religions but a state guarantee for safeguarding religious freedom in a régime of denominational and cultural pluralism"). It has been recently argued that the court's recent approach is less active, as in two recent cases, it defined the principle of secularism as "equidistance and impartiality" of the state with regard to religious faith. See Pietro Faraguna, Regulating Religion in Italy: Constitution Does (Not) Matter (under review, copy with author) (referring to Corte Cost., 2000, n. 508 and Corte Cost., 2016, n. 52).

52. Racc. uff. Corte Cost., 12 aprile 1989, n. 203 (It.), http://www.olir.it/documenti/?documento=370 [https://perma.cc/WZH6-XLT4].

53. Art. 2 Costituzione [Cost.] (It.).

54. See, e.g., Pietro Faraguna, Ai confini della Costituzione. Principi SUPREMI E IDENTITÀ COSTITUZIONALE 69-72 (2015) (It.); Paolo Galizzi, Constitutional Revisions and Reforms: The Italian Experience, in THE CREATION AND AmENDMENT of Constitutional Norms 235, 241 (Mads Andenas ed., 2000); Tania Groppi, Constitutional Revision in Italy: A Marginal Instrument for Constitutional Change, in Engineering Constitutional Change: A Comparative Perspective on Europe, Canada And the USA 203, 210 (Xenophon Contiades ed., 2013); Carlo Fusaro, Italy, in How Constitutions Change: A Comparative STUDY 211, 215 (Dawn Oliver \& Carlo Fusaro eds., 2011). 
to the principle of constitutional revision, are part of the supreme values on which the Italian Constitution is based. ${ }^{55}$

Therefore, taking decision number 203/1989 together with decision number 1146/1988 would mean that notwithstanding the explicit protection of republicanism, the Italian Constitutional Court recognized additional supreme constitutional principles that are unamendable, secularism being one of them.

Italy is not the only example where secularism was considered as an unamendable or eternal principle by a court's decision, deriving this implicitly from the constitution. India is another important jurisdiction where secularism has been declared by the Court to be an implicitly entrenched principle.

The Preamble of the 1950 Indian Constitution opens with the following declaration: "We, The People of India, having solemnly resolved to constitute India into a Sovereign Socialist Secular Democratic Republic and to secure to all its citizens . . . ." ${ }^{56}$ Indian secularism functions in a manner that supports religious identity. Following the maxim sarva dharma sambhava ("all religions are valid"), India's constitution was aimed to respect all religions. ${ }^{57}$ This in turn enabled the application of secular law to all areas of the law but family law, to which religious communities could be governed by their particular set of laws. ${ }^{58}$ Of course, a long discussion on secularism in India is beyond the narrow scope of this Article. ${ }^{59} \mathrm{My}$

55. Racc. uff. Corte Cost., 15-29 dicembre 1988, n. 1146 (It.), http://www.cortecostituzionale.it/actionSchedaPronuncia.do?anno=1988\&numero=1 146 [https://perma.cc/2KAV-3WZ9]. Cited at Louis Del Duca and Patrick Del Duca, Emergence of the Italian Unitary Constitutional System, Modified by Supranational Norms and Italian Regionalism in FeDERALISM AND LEgal UNIFICATION 267, 273 (Daniel Halberstam and Mathias Reimann eds., 2014).

56. INDIA CONST. pmbl.

57. Cyra Akila Choudhury, (Mis)Appropriated Liberty: Identity, Gender Justice and Muslim Personal Law Reform in India, 17 COLuM. J. GENDER \& L. 45, 47 (2008).

58. See id.

59. Much has been written on secularism in India. See, e.g., Donald Eugene Smith, India as a Secular State (1963); M. M. Sankhder, Secularism in India: Dilemmas and Challenges (1992); SARal Jhingran, Secularism in India: A ReAPPRAISAl (1995); MANVINDER KaUR, ChallengeS TO SECUlarism IN India: The Constitutional Ideal, Political Process, and Prospects (1999); S. K. Ghosh, Secularism in India: The Concept and Practice (2001); Gary JEFFREY JACOBSOHN, THE WhEEL OF LAW: INDIA's SECULARISM IN COMPARATIVE Constitutional Context (2003); The Crisis of Secularism in India (Anuradha Dingwaney Needham \& Rajeswari Sunder Rajan eds., 2007); M. Mohsin Alam, Constructing Secularism: Separating 'Religion' and 'State' Under the Indian 
aim here is to briefly demonstrate how secularism, as a constitutional principle, has become an implicit eternal principle in Indian jurisprudence.

In contrast with other states, such as Turkey, Portugal, or Chad ${ }^{60}$ in India, secularism is not an explicit unamendable or eternal principle. Indeed, the Indian Constitution lacks any unamendable provisions whatsoever. Moreover, rooted in British tradition, Indian jurisprudence initially rejected the notion of implicit unamendability. That position, however, drastically changed in the 1960s and 1970s following Prime Minister Indira Gandhi's extensive attempts to amend the constitution. These events led to the judicial development of what has become known as the "Basic Structure Doctrine." According to this doctrine, developed in the famous Kesavananda case in the early 1970 s, the constitutional amendment power does not include the power to abrogate or change the identity of the constitution or its basic features. ${ }^{61}$ This Doctrine has since migrated from India to other jurisdictions. ${ }^{62}$

While the question of which principles are included within this basic structure is contentious, it appears that it is undisputed today that it includes, at the very least, the principle of secularism alongside other principles such as the democratic form of government, federalism, judicial independence, and the separation of powers. ${ }^{63}$ Indeed, already in the Kesavananda case, several judges

Constitution, 11 Austl. J. Asian L. 29-55 (2009); DomeniC Marbaniang, SECUlarism In India: A Historical ANALysis (2011); RAJEEV Bhargava, SeCUlarism AND Its CRITICS (2014); Ronojoy Sen, Secularism and Religious Freedom, in THE OXFord HANDBOOK of THE Indian CONSTITUTION 885 (Sujit Choudhry, Madhav Khosia \& Pratap Bhanu Mehta eds., 2016).

60. See infra Section II.A.

61. Kesavananda Bharati v. State of Kerala, AIR 1973 SC 1461 (India). On the case and the Basic Structure Doctrine, see, e.g., A. LAKSHMINATH, BASIC Structure and CONSTitutional AMENDMENTS: Limitations AND Justiciability 134-85 (2002); SudHIR Krishnaswamy, DemOCRACY AND CONSTITUTIONALISM IN India: A Study OF THE BASIC StRUCture Doctrine 43 (2009); T. R. Andhyarujina, The Kesavananda Bharati Case-The Untold Story of Struggle for Supremacy by Supreme Court And Parliament (2011).

62. Yaniv Roznai, The Migration of the Indian Basic Structure Doctrine, in Judicial ACTIVISM In India: A Festschrift in Honour of Justice V. R. KRISHNA IYER 240 (Malik Lokendra ed., 2012).

63. Sujit Choudhry, How to Do Constitutional Law and Politics in South Asia, in Unstable Constitutionalism 18, 21-22 (Mark Tushnet \& Madhav Khosla eds., 2015). Of course, the content of each of these principles may in itself be open to disagreements. 
opined that secularism is part of the Constitution's basic structure. ${ }^{64}$ In the case of $R$. C. Poudyal v. Union of India, the principle of secularism was held to be a basic feature of the Constitution, one among the Constitution's foundational principles to which parliament must adhere. ${ }^{65}$

The clearest manifestation for this was given in the case of $S$. R. Bommai v. Union of India, which concerned dismissals of state governments in Madhya Pradesh, Himachal Pradesh, and Rajasthan on the basis that the actions of these governments undermined the secular foundations of the Constitution. ${ }^{66}$ The dismissal was upheld on the ground that governmental officials in these states had violated the requirement of secular governance:

Secularism is a part of the basic structure of the Constitution. The acts of a State Government which are calculated to subvert or sabotage secularism as enshrined in our Constitution, can lawfully be deemed to give rise to a situation in which the government of the State cannot be carried on in accordance with the provisions of the Constitution. ${ }^{67}$

The idea that secularism is an "unalienable segment of the basic structure of the country's political system" was once again confirmed in the case of Praveen Bhai Togadia v. State of Karnataka. $^{68}$

64. See Kesavananda, at 292 (Sikri J), 582 (Shelat \& Grover JJ) (India).

65. R. C. Poudyal v. Union of India, (1994) Supp. 1 SCC 324; see also, e.g., Ashok Dhamija, Need to Amend a Constitution and Doctrine of Basic Features 339 (2007); Sudhir Krishnaswamy, Constitutional Federalism in the Indian Supreme Court, in UnStable Constitutionalism, supra note 63, at 320, 366; LAKSHMINATH, supra note 61, at 225-28.

66. S. R. Bommai v. Union of India, (1994) 3 SCC 1, 1 (India). See Soli J. Sorabjee, Decision of the Supreme Court in S.R. Bommai v. Union of India: A Critique, http://www.ebc-india.com/lawyer/articles/94v3a1.htm\#Note169 [https:// perma.cc/E69P-9FET] (last visited Apr. 20, 2017).

67. JACOBSOHN, supra note 59, at 126 (citing Bommai, 3 SCC at 149 (India)). According to Justices Sawant and Kuldip Singh, actions that go counter to the creed of secularism are prima facie proof of conduct in defiance of the provisions of our Constitution. Bommai $3 \mathrm{SCC}$ at 5. Justice Sawant, for example, referred to a destruction of a mosque in Ayodhya, stating that:

The destruction of mosque was a concrete proof of the creed which the party in question wanted to pursue. In such circumstances, the Ministries formed by the said party could not be trusted to follow the objective of secularism which was part of the basic structure of the Constitution and also the soul of the Constitution. JACOBSOHN, supra note 59, at 145 (citing Bommai 3 SCC at 3 (India)).

68. Praveen Bhai Togadia v. State of Karnataka, AIR 2004 SC 2081 (India). The case concerned hate speech. The Supreme Court held that the judiciary is 
This means that in India, according to the current prevailing jurisprudence, the constitutional principle of secularism cannot be revised through formal constitutional amendments. As the court stated in Bommai: "[W]e do not know how the constitution can be amended so as to remove secularism from the basic structure of the constitution ... it is enough for us to know that the constitution does not provide for such a course. $"$ ${ }^{9}$

This story about explicit and implicit protection of secularism as an unamendable principle points prima facie to provide a positive answer to the question I posed in the beginning of this Article; yes, in some states, secularism is non-negotiable by the mere fact that it is described as an eternal, unamendable principle. In that respect, Michel Rosenfeld is certainly right to claim that "ideological secularism seeks ... protection from others, including religions, which stand in the way of the path to the good it has set out for itself." 70 The use of constitutional mechanisms for shielding secularism from being amended or completely abolished is one manner for such a "protection."

In the next Section, I analyze three case studies of states, which protect in their constitutions secularism as an eternal principle, to examine whether the designation of eternity means non-negotiability. I demonstrate how the mere description of a constitutional principle as eternal or unamendable does not mean it is not open for modifications.

\section{ETERNAL YET NEGOTIABLE?}

This second Part is the core of the Article. It opens with three case studies focusing on three states with a majority-Muslim population: Turkey, where the state's new founder, Mustafa Kemal Atatürk, established a modern secular republic rejecting an Ottoman legacy; Tajikistan, where the secular approach is a direct continuation of the Soviet's control and suppression of religions; and Mali, where secularism was inherited from its former colonial ruler, France. All three states protect secularism as an eternal principle.

empowered to limit freedom of expression if the inflammatory speech aims to incite mutual hatred that is likely to create disharmony and disturb the public peace.

69. JACOBSOHN, supra note 59, at 141 (citing Bommai, 3 SCC at 13 (India)).

70. Michel Rosenfeld, Recasting Secularism as One Conception of the Good Among Many in a Post-Secular Constitutional Polity, in Constitutional Secularism in an Age of Religious Revival 79, 108 (Susana Mancini \& Michel Rosenfeld eds., 2014). 
The case studies explore various tensions within the state-religion divide and various circumstances that have influenced the secular principle. It then continues to argue that notwithstanding the designation of a constitutional principle as eternal, it is still prone to changes and modifications. First, constitutional provisions which are not self-entrenched may simply be formally amended. Second, the principle of secularism does not carry a monolithic meaning. In light of its vague and elastic nature, it is open to various interpretations and reinterpretations. Finally, especially when the formal written constitution conflicts with the often changing spirit or culture of the society, the ability of the formal written constitution to hinder or stop changes is limited. Constitutional principles may be described as eternal, but they cannot completely resist changes.

\section{A. Three Case Studies}

Does the absolute entrenchment of secularism in a constitution mean that it is non-negotiable? This section examines the situation in three jurisdictions that include in their constitutions the principle of secularism as an eternal principle: Turkey, Tajikistan, and Mali. This examination is aimed to demonstrate that constitutional immutability (in the sense of describing certain principles as immutable) does not necessarily mean constitutional stagnancy.

\section{Turkey}

There is a huge volume of literature on the role secularism plays in Turkey. ${ }^{71}$ Hence, this section merely briefly highlights the so-called eternal protection of secularism in Turkey and describes, as I regard it, its changing nature.

The legal order of the Ottoman state, which existed for over six centuries (1280 to 1922), was based on Islamic religious law-the

71. See, e.g., Zeyno Baran, Torn Country: Turkey Between SECUlarism AND Islamism (2010); Democracy, Islam \& SECUlarism In TuRKey 1-2 (Ahmet T. Kuru \& Alfred Stepan eds., 2012); NiYAZI Berkes, The Development of Secularism in Turkey 4 (1998); Ümit Cizre, Secular and ISLAMIC POLITICS IN TURKeY: THE MAKING OF THE JUSTICE AND DEVELOPMENT PARTY (2008); Bora Kanra, Islam, Democracy and Dialogue in Turkey: Deliberating in Divided Societies (2009); M. Hakan Yavuz, Secularism AND MuSLIM DEMOCRACY IN TURKEY 144 (2009). 
Sharia. ${ }^{72}$ In 1923, the Republic of Turkey was founded as a nationstate. The new republic's founders, most notably, Mustafa Kemal Atatürk, the Turkish republic's founder, rejected the Ottomans legacy and aimed to establish a westernized society based on the modern paradigm of secularism (laiklik). ${ }^{73}$ Accordingly, in 1924, the caliphate was abolished, and a new constitution was adopted. The new constitution declared in Article 2 Islam as the official religion of the state, yet in 1928 this constitutional provision was repealed. In 1937, the principle of laiklik received a constitutional status in Article 2 in order to "better reflect modern Turkey's adherence to a strict separation of state and religion." ${ }^{74}$ This official state policy of laiklik was established in both the later 1961 and 1982 constitutions. $^{75}$

In the 1982 constitution, the preamble states that there should be "no interference whatsoever of sacred religious feelings in state affairs and politics," and Article 1 declares Turkey a republic. ${ }^{76}$ Article 2 specifies that the republic is a "democratic, secular and social state governed by the rule of law; bearing in mind the concepts of public peace, national solidarity and justice; respecting human rights; loyal to the nationalism of Atatürk, and based on the fundamental tenets set forth in the Preamble." 77 Most importantly for this study, according to Article 4, both Article 1 and Article 2which establish the form of the state as a republic and specify its characteristics - may not be amended and their amendment may not be proposed. ${ }^{78}$ Accordingly, the Turkish principle of secularism is

72. See Ergun Özsunay, The Permissible Scope of Legal Limitations on the Freedom of Religion or Belief in Turkey, 19 EMORY INT'L L. REV. 1087, 1087 (2005).

73. See Serdar Demirel, The Roots of Headscarf Ban in Turkey, 5 J. IsLAm IN ASIA 164-65 (2008). On the historical roots of Kemalism in Turkey, see M. Şükrü Hanioğlu, The Historical Roots of Kernalism, in DemOCRACY, IsLAm \& SECUlarism IN TURKEY, supra note 71, at 32-60.

74. RAN Hirschl, CONSTItUtional TheOcracy 27 (2010); see also Benjamin D. Bleiberg, Unveiling the Real Issue: Evaluating the European Court of Human Rights' Decision to Enforce the Turkish Headscarf Ban in Leyla Şahin v. Turkey, 91 CORNELL L. REV. 129 ,134 (2005).

75. HIRSCHL, supra note 74, at 27.

76. CONSTITUTION OF THE RePUblic OF TURKEY $1982 \mathrm{pmbl}$. and art. 1.

77. Id. at pt. I, art. 2.

78. On unamendable provisions in Turkey, see, e.g., Bertin Emrah Oder, Turkey, in The 'Militant Democracy' Principle in Modern Democracies 263310 (Markus Thiel ed., 2009); see also Olcay, supra note 40; Gülşen Seven \& Lars Vinx, The Hegemonic Preservation Thesis Revisited: The Example of Turkey, 9 Hague J. Rule L. 45, 45 (2017). 
granted the highest normative protection, shielding it from any attempts that seek to change its existence as a constitutional norm through formal revisions to the constitution. ${ }^{79}$

One important manifestation of the special protection granted to the principle of secularism is the ban on political parties that aims to abolish secularism. ${ }^{80}$ The Turkish Constitutional court shut down six parties under the 1961 constitution, and eighteen parties under the constitution of 1982; many of these dissolutions have been based on alleged violations of the protected principle of secularism. ${ }^{81}$

The best way in which this unamendability has managed to protect secularism can be examined through the lenses of the headscarf debate in Turkey. One of the most important symbolic aspects of the modern Turkey was the "dress code reform" declared by Atatürk in 1925. The Headgear Act of 1925 banned the traditional head cover for men $(f e z)$ who were obliged to wear European-style hats. ${ }^{82}$ Soon after, in 1930, the Islamic veil was banned. The Dress (Regulation) Act of 1934 banned wearing religious dress other than

79. Mehmet Cengiz Uzun, The Protection of Laicism in Turkey and the Turkish Constitutional Court: The Example of the Prohibition on the Use of the Islamic Veil in Higher Education, 28 PENN. ST. INT'L L. REV. 383, 399 (2010).

80. See generally Dicle Kogacioglu, Progress, Unity, and Democracy: Dissolving Political Parties in Turkey, 38 L. \& Soc'Y Rev. 433, 433-34 (2004).

81. See Svetlana Tyulkina, Militant Democracy: Undemocratic Political PARTIES AND Beyond 169 (2015). Indeed, the ban on the function of certain political parties can be viewed as an ex-ante eternity provision, since it aims to block political parties that aim to change or abolish the fundamentals of the constitutional order from even being elected, thereby from even having the political ability to suggest a change to the constitution's basic principles. See, e.g., Sharon Weintal, The Challenge of Reconciling Constitutional Eternity Clauses with Popular Sovereignty: Toward Three-Track Democracy in Israel as a Universal Holistic Constitutional System and Theory, 44(3) IsR. L. REV. 449, 468 (2011) (who argues that the Israeli ban on political parties "sets the barrier against revolutionary amendments not at the end of the road, in order to strike them down following their ratification, but at the gates of the constituent assembly, thereby neutralizing their potential initiators"). On the Nexus between eternity clauses and the ban on political parties, see also Rivka Weill, Holey Union: The Constitutional Paradox of SECESSION (2014), https://ssrn.com/abstract=2708859 [https://perma.cc/2V8ZBZJ8]; see also Mazen Masri, Unamendability in Israel-A Critical Perspective, in AN UnCONSTitutional Constitution? UnAmEndability in Constitutional DEMOCRACIES, supra note 2, https://ssrn.com/abstract=2840941 [https://perma.cc/L7ZSQNS3].

82. See Yaniv Roznai \& Serkan Yolcu, An Unconstitutional Constitutional Amendment-The Turkish Perspective: A Comment on the Turkish Constitutional Court's Headscarf Decision, 10 INT'L J. CONST. L. 175, 178 (2012) (citing Turkey's Act No. 671 of 25 November 1341 (1925) on the Wearing of Hats). 
in places of worship or at religious ceremonies. ${ }^{83}$ The fez and veil were considered symbols of the old regime, which conflicted with modernization and secularization. ${ }^{84}$ These measures were aimed at creating religion-free zones where all citizens would be treated equally and without distinction on religious grounds. ${ }^{85}$

In the 1980 s, when young educated women began wearing the Islamic headscarf in public places, such as universities, the issue arose once again. As the policy was that Islam cannot exist in a place of education, university administrations prohibited female university students from wearing headscarves at universities. ${ }^{86}$ In 1981, a first set of regulations prohibiting female staff members and students from wearing veils in higher educational institutions was issued by the cabinet. The following year, the Council of Higher Education (Yüksek Öğretim Kurulu or YÖK) banned the Islamic headscarf in university lecture halls. ${ }^{87}$ These regulations were challenged before the Council of State, the highest administrative court, which approved them on the basis that "wearing the headscarf is in the process of becoming the symbol of a vision that is contrary to the freedoms of women and the fundamental principles of the Republic." ${ }^{88}$ In response to these measures, in 1984 the majority Motherland Party [Anavatan Partisi] passed a law according to which "[a] veil or headscarf covering the neck and hair may be worn out of religious conviction." ${ }^{89}$ The President of the republic challenged the law before the Constitutional Court, and the Court annulled the provision, holding that it was contrary to Articles 2 (secularism), 10 (equality before the law), and 24 (freedom of religion) of the Constitution. The Constitutional Court explained that secularism—an

83. See id. (citing Turkey's Act No. 2596 of 3 December 1934 on the Prohibition of the Wearing of Certain Garments).

84. Demirel, supra note 73, at 166-67.

85. In the current 1982 Constitution, these bans receive a constitutional protection in Art. 174, according to which "[n]o provision of the Constitution shall be construed or interpreted as rendering unconstitutional the Reform Laws . . . which aim to . . . safeguard the secular character of the Republic." CONSTITUTION OF THE REPUBLIC OF TURKEY pt. V, art. 174.

86. William Hale \& Ergun Özbudun, Islamism, Democracy and LIBERALISM IN TURKEY 71 (2010). For an elaborated review of the headscarf ban in universities in Turkey, see Fatma Nevra Seggie, Religion and the State in TURKISH UNIVERSITIES: THE HEADSCARF BAN 30-39 (2011).

87. See SEGGIE, supra note 86 , at 30-39.

88. See Leyla Şahin v. Turkey, 2005-XI; 44 EHRR 99 GC. Grand Chamber's decision, \ 37 (Turk.).

89. See id. at 138. 
essential condition for democracy — prohibits the state from showing a preference for a particular religion or belief, and that a secular state cannot invoke religious conviction when performing its legislative function. Once outside the private sphere of individual conscience, the freedom to manifest one's religion could be restricted on publicorder grounds to defend the principle of secularism. ${ }^{90}$ After this judgment, Anavatan Partisi enacted another law in 1990, according to which "[c]hoice of dress shall be free in institutions of higher education, provided that it does not contravene the laws in force." 91 Again, this law was challenged before the Constitutional Court by the main opposition party. In 1991, the Constitutional Court held that, in light of the principles it had established in its earlier 1989 judgment, this provision did not allow headscarves to be worn in institutions of higher education on religious grounds and so was consistent with the Constitution. ${ }^{92}$ In other words, while not invalidating the new law, the Court interpreted it in a way that still prohibited wearing headscarves in universities. Accordingly, the ban on wearing headscarves in universities was not based on statutory law but was practically imposed by public bodies based upon the two above-mentioned judicial decisions. ${ }^{93}$

In light of the fact that, for years, female university students could not exercise their right to education because of dress that they use to cover their heads, in 2008, the Turkish Grand National Assembly adopted an amendment to the constitution regarding the principle of equality and the right to education with the explicit aim

90. Constitutional Court Decision, E. 1989/1, K. 1989/12, March 7, 1989, Anayasa Mahkemesi Kararlar Dergisi [Constitutional Court Reports], No.25, 13365. The Court stated that "[s]ecularism is the civil organiser of political, social and cultural life, based on national sovereignty, democracy, freedom and science. Secularism is the principle which offers the individual the possibility to affirm his or her own personality through freedom of thought and which, by the distinction it makes between politics and religious beliefs, renders freedom of conscience and religion effective. In societies based on religion, which function with religious thought and religious rules, political organisation is religious in character. In a secular regime, religion is shielded from a political role. It is not a tool of the authorities and remains in its respectable place, to be determined by the conscience of each and everyone...." Id. at 939.

91. See Roznai \& Yolcu, supra note 82, at 180 (citing Turkey's Law No. 2547 (1981)).

92. See Constitutional Court Decision, E. 1990/36, K. 1991/8, April 9, 1991, Anayasa Mahkemesi Kararlar Dergisi [Constitutional Court Reports], vol. 1, 285-323.

93. See Ergun Özbudun, Judicial Review of Constitutional Amendments in Turkey, 15 European Pub. L. 533, 537 (2009). 
to preclude the possibility of discrimination by the universities based upon religious grounds, and to eliminate any deprivation of the right to an education in higher education institutions. The underlying purpose was to abolish the headscarf ban in universities. The constitutional amendment was challenged before the Turkish Constitutional Court. On June 5 of that year, the Constitutional Court delivered a controversial decision in which it invalidated the amendments to the Constitution. ${ }^{94}$ Since I have elaborated on this judgment elsewhere (together with Serkan Yolcu), it is sufficient for now simply to note that the Turkish Constitutional Court ruled that these amendments infringed on the constitutionally enshrined principle of secularism and were therefore unconstitutional. ${ }^{95}$

Turkey is therefore rather unique, because it is where the Court actually protects or enforces this unamendability or eternity of the secularism principle through substantive judicial review of constitutional amendments. ${ }^{96}$ But for our matter, the importance is

94. Turkish Constitutional Court decision, June 5, 2008, E. 2008/16; K. 2008/116, Resmi Gazete [Official Gazette], October 22, 2008, No. 27032, 109-52 ("Headscarf Decision of 2008"). On the "headscarf" amendment and the constitutional crisis, see also ERgun ÖzBudun \& ÖMER F. GENCKAYA, Democratization and the Politics of Constitution-Making in Turkey 106-09 (2009); see also Mehmet Cengiz Uzun, The Protection of Laicism in Turkey and the Turkish Constitutional Court: The Example of the Prohibition on the Use of the Islamic Veil in Higher Education, 28 PenN. St. InT'L L. ReV. 383 (2009); Abdurrahman Saygili, What Is Behind the Headscarf Ruling of the Turkish Constitutional Court?, 11 TURKISH STUD. 127, 131 (2010).

95. See Roznai \& Yolcu, supra note 82, at 175. Yolcu and I have criticized this judgment on various grounds. Specifically as for the principle of secularism, we have claimed that the wearing of religious symbols by students in universities (in contrast with that of teachers in primary schools) reflects the choice of individuals to adhere to their cultural and religious identity when entering the public sphere; it has no bearing on the secularism principle enshrined in a constitution, which obliges the state to act in a neutral manner with respect to religious identity, to separate state and religion, and to provide a civil-secular state education. See also Uzun, supra note 94, at 425 ("[I]n a democratic state the use of a religious symbol by an individual should eventually be seen under the auspices of the enjoyment of fundamental rights and freedoms, and religion per se should not be construed as an abstract risk to a secular/laic democratic state apparatus.").

96. Following the headscarf ban case, Yolcu and I have argued that: "The lesson for the future Turkish constitutional debate should be clear: the judicial review of constitutional amendments ought to be limited to formal regularity." Roznai \& Yolcu, supra note 82, at 206. Indeed, in a more recent decision on parliamentary immunity of June 3, 2016, the Turkish Constitutional Court held that in light of the explicit constitutional ban on substantive (in contrast with procedural) review of constitutional amendments, it could not substantively review the constitutionality of an amendment. This contradiction reveals inconsistency in the 
not in this abolishment of a constitutional amendment, but with the events that have occurred in the aftermath of this judgment.

After the Constitutional Court's decision, and especially with the resistance the government encountered in its attempt to draft a new constitution, the government was left with no available legal channels to address the headscarf ban. This led the party to resort to sub-constitutional administrative measures to achieve its goals. Indeed, in 2010 it found a de facto solution to the issue. After receiving a complaint from a female university student who was expelled from a classroom due to her refusal to take off her hat (which was a practical replacement for the headscarf), the Council of Higher Education issued a formal order to the university that students who disobey the disciplinary code may not be expelled from class. In other words, instead of expelling students wearing headscarves from the classrooms, such students may only be reported. This order managed to create a bypassing channel to circumvent the headscarf ban in universities, de facto ending it. ${ }^{97}$ No legal actions were brought against this lift of the headscarf ban.

\section{Tajikistan}

Tajikistan, one of five Central Asian countries with a majority Sunni population, presents a special case of the conflict between secularism and religion; during its contemporary history, a long confrontation between secular and religious groups challenged the secular character of the state. ${ }^{98}$

Tajikistan's Constitution of 1994 states that the country is a democratic and secular republic (Article 1) and, more relevant to our study, includes in Article 100 an unamendable provision according to which among other principles, "The secular ... nature of the State

court's jurisprudence in enforcing constitutional unamendability. For an analysis, see Richard Albert, Constitutional Amendment and Dismemberment; 43 YALE J. InT'L L. (forthcoming 2018); Boston College LaW School Legal Studies RESEARCH PAPER No. 424, at 89 (November 25, 2016), https://ssrn.com/abstract= 2875931.

97. Ahmet T. Kuru \& Alfred Stepan, Laicite as an "Ideal Type" and a Continuum, in Democracy, IsLAm \& SECULARISM IN TURKEY, supra note 71, at 95, 104; see also Zafer Çelik \& Bekir S. Gür, Turkey's Education Policy During the AK Party Era (2002-2013), 15 Insight TuRK. 151, 167-68 (2013); Seven \& Vinx, supra note 78, at 45; Seval Yildirim, Global Tangles: Laws, Headcoverings and Religious Identity, 10 SANTA CLARA J. INT'L L. 45, 64 (2012).

98. See Hakim Zainiddinov, The Changing Relationship of the Secularized State to Religion in Tajikistan, 55 J. CHURCH \& ST. 456 (2013). 
[is] unchangeable." ${ }^{99}$ Moreover, Article 2 of the Constitutional Law of the Republic of Tajikistan on Referendum explicitly refers to "[i]ssues beyond referendum of the Republic of Tajikistan," stating that "in accordance with Article 100 of the Constitution of the Republic of Tajikistan ... [the] secular. . . essence of the state [is] ... immutable and ... not subject to solicitation by referendum in the Republic of Tajikistan." ${ }^{100}$ Therefore, the principle of secularism is considered an unamendable constitutional principle.

Tajikistan's approach toward religions "is a continuation of the Soviet method of control and suppression of religion and religious organizations." 101 However, Tajikistan is a predominantly Muslimpopulated country, where Islam takes a central part in their social and economic life. This meant that the declaration of the state was a secular one, coercively (and in a way artificially) separating Islam from the state. As Hakim Zainiddinov demonstrates, notwithstanding the declaration of the state as secular, the Tajikistani government was connected with religious institutions and even also announced an adherence to Islamic values. ${ }^{102}$ Tajikistan, for example, is the only Central Asian country to officially register an Islamic political party. In 1991, when Tajikstan gained independence, the Islamic Revival Party of Tajikistan (IRPT) was officially registered. ${ }^{103}$

Soon after the 1991 declaration of independence, a power struggle between the neo-communist government and a heterogeneous opposition, in which the IRPT emerged as a very significant actor, coupled with strong regional forces, brought the new state to a five-year devastating civil war (1992-1997) with significant consequences for a population of seven million

99. Constitution of THE Republic of TAJikistan 1994 arts. 2, 100.

100. Constitutional Law of the REPUblic of TaJikistan On REFERENDUM IN THE REPUBLIC OF TAJIKISTAN 1995 art. 2.

101. Under Soviet rule, the state was clearly anti-religious, seeking to weaken and ultimately diminishing political and financial power of religious institutions. See Zainiddinov, supra note 98, at 457. Among other measures, courts that apply Sharia were banned, religious schools and mosques were closed, Waqf lands were confiscated, and religious clergies were arrested. Id. On the "Soviet assault on Islam," see generally, AdeEB KHALid, IsLAm AfTer COMMUNiSM: RELIGION AND POLITICS In CENTRAL Asia 50-83 (2007).

102. See Zainiddinov, supra note 98 , at 456.

103. See id. at 458 . 
inhabitants: around $100,000 \mathrm{dead}, 800,000$ people fleeing their homes and a destroyed economy and socio-political life. ${ }^{104}$

In November 1991, Rahmon Nabiyevich Nabiyev, a former first secretary of the Communist Party of Tajikistan, won the Presidential election; a win that led to protests (mainly from the eastern part of the country) from both pro-democracy parties and the IRPT. Nabiyev's supporters, mainly from the southern part of the country, reacted with counter-protests. The clashes between the two groups broke out in Dushanbe and spread across the south of Tajikistan, resulting in the start of the civil war. The events forced Nabiyev to negotiate with opposition leaders on power-sharing, negotiations that have resulted in 1992 with an establishment of a coalition government that included Islamist and pro-democratic forces. The same year, President Nabiev was forced to resign, ${ }^{105}$ and soon after, the coalition government was defeated by the "People's Front" composed of southern armed groups supported by Russia, Uzbekistan, and the country's northern part. This brought President Emomali Rahmon to power, and soon after, the government attempted to restore its control in religious affairs, banning, in 1993, the IRPT from operating. ${ }^{106}$

With Russian and Uzbekistani support, the Rahmon government decided to continue its armed combat up to the defeat of the United Tajik Opposition (UTO). In 1996, after years of military fighting, the confronting sides agreed to cease-fire and negotiate. After negotiations in Moscow, an Agreement on the Establishment of Peace and National Accord was signed in 1997 to settle the conflict. ${ }^{107}$ The Agreement started a new era in state-religion relationships as it guaranteed that the UTO would take part in ruling all government sectors based on a thirty percent quota allocated to its representatives. Supporters of the Islamic Revival Party made up the majority of the opposition. ${ }^{108}$

Notwithstanding the peace agreement, tensions between the religious and secular sides remained high, particularly around the

104. Id. at 459-60. See Shirin Akiner, Prospects for Civil Society in Tajikistan, in Civil Society IN THE Muslim World: Contemporary Perspectives 149, 160 (Amyn B. Sajoo ed., 2002).

105. Id. at 460 .

106. Id.

107. See id.

108. Id.; see also Tim Epkenhans, Regulating Religion in Post-Soviet Central Asia: Some Remarks on Religious Association Law and "Official" Islamic Institutions in Tajikistan, 20 SECURITY \& HUM. RTS. 94, 95 (2009). 
nature of the secular state. The secular side considered secularism to be non-religious rather than anti-religious. ${ }^{109}$ As noted by Sayfullo Safarov, the secular side intended "to be free from any influences of various religions." 110 In contrast, the religious side considered secularism as anti-religious. They regarded the protection of the principle of secularism as a "safety measure" against the option of turning to a religious state. ${ }^{111}$ Thus, the religious groups insisted on excluding the term "secular state" from Articles 1 and 100 of the Constitution of the Republic of Tajikistan. ${ }^{12}$ Such a maneuverer would have allowed the future modification of the state away from its secular nature. In fact, as pointed out by Grant Smith, whereas the religious side "did not want to foreclose the option of an Islamic government ... [g]overnment leaders, in contrast, strongly opposed any opening to possible creation of an Islamic State." 113

The dialogues between the conflicting groups resulted in a compromise, which kept Article 100 on the unamendability of the secular nature of the state in the constitution. At the same time, it introduced an amendment to Article 28 to the Constitution that allowed religious parties to function in the country. These changes were incorporated into the Constitution by a people's referendum in $1999 .{ }^{114}$ In other words, the compromise maintained the recognition of the secular character of the state by the religious groups in exchange for the legalization of religious parties and power sharing. These changes enabled the IRPT to legalize and legitimize itself in 1999 after being banned in 1993. IRPT's leadership realized that they had to compromise over the initial goal of broadly spreading Islam, as outlined in the IRPT's charter of $1991 .{ }^{115}$ The leadership of the IRPT emphasized the necessity to adhere to the secular nature of the state. They declared that Islamist political organizations and

109. Zainiddinov, supra note 98, at 461.

110. Sayfullo Safarov, Searching for a Compromise: Proposals for Consolidating Confidence Between Representatives of Secular and Islamic Worldviews, in From CONFIDENCE BuILding TOWARdS CO-OPERATIVE CoEXISTENCE: The TAJIK EXPERIMENT Of IslamiC-SeCular Dialogue 192, 194 (JeanNicolas Bitter et al. eds., 2005).

111. Muhiddin Kabiri, The Hermeneutics of the Dialogue to Achieve a Secular-Islamic Compromise in Tajikistan, in From CONFIDENCE BUILDING TOWARDS CO-OPERATIVE CO-EXISTENCE, supra note 110, at 199, 201.

112. Zainiddinov, supra note 98 , at 461.

113. R. Grant Smith, Tajikistan: The Rocky Road to Peace, 18 CENT. ASIAN SURV. 243, 246 (1999).

114. Zainiddinov, supra note 98 , at 462 .

115. Id. 
parties cannot put their interests over the state's interests. Therefore, if they win the elections, they would govern in accordance with the secular constitution without jeopardizing the state's secular character. The IRPT's new charter of 1999 introduced these changes to its goals and strategies. ${ }^{116}$

The compromise allowing the functioning of religious political parties was therefore considered as not changing the secular nature of the state, even if religious parties win a high percentage of votes, because they would have to act within the secular nature of the constitutional order as guaranteed by Article 100. ${ }^{117}$

This compromise was not easy for any of the sides. Before 1992, the IRPT posed political Islam as its ideology. ${ }^{118}$ After the start of the civil war, it joined the armed opposition, implicitly fighting for the establishment of an Islamic State. After the signing of the 1997 peace agreement with its new 1999 charter, the IRPT has become a modern political party, which avoids any suggestion that Tajikistan should advance toward becoming an Islamic State. Instead of considering the role of Islam as an element for society's radical reconstruction, the IRPT changed its perception to the role of Islam as a national, spiritual, and cultural element. ${ }^{119}$

As for the Tajikistani government, which inherited the legacy of the Soviet ruling regime, allowing the outlawed opposition parties to function legally was also a difficult decision to make. Yaacov Ro'i argued that the Soviet heritage envisaged intolerance toward the existence of any opposition and a strict separation of church from the state. ${ }^{120}$ For some, it might even have been difficult to grasp the idea of how religious political parties can coexist with the secular state. Some of the secular population regards Islam as an uncompromising religion, which brings the fear that even if Islamists can accept some limited compromises, there is always a dangerous potential for quick radicalization. ${ }^{121}$ Therefore, whereas the government allowed the legalization of opposition religious parties, it simultaneously

116. Id. at 463 .

117. Muhiddin Kabiri, The Tajik Experience of a Multiparty SystemException or Norm?, in Prospects For Democracy in Central Asia 21, 24 (Birgit N. Schlyter ed., 2003).

118. Emmanuel Karagiannis, The Challenge of Radical Islam in Tajikistan: Hizb ut-Tahrir al-Islami, 34 NATIONALITIES PAPERS 1, 12 (2006).

119. See id.

120. Yaacov Ro'i, Islam in the FSU-An Inevitable Impediment to Democracy?, in Democracy AND PluRAlism in Muslim EuRASIA 101, 102 (Yaacov Ro'i ed., 2004).

121. Zainiddinov, supra note 98 , at 474 . 
tightened its control over religion, limiting the public space for religious associations. ${ }^{122}$

Following the end of the civil war, Tajikistani society has become increasingly conservative, with social ills-such as prostitution and human trafficking, alcoholism, and drug use together with high levels of unemployment and widespread povertycontributing to the popularity of radical religious groups and the revival of "Muslim values." This is evident, for instance, by the revival of polygamy and the growing number of women wearing a hijab. ${ }^{123}$ Consequently, underground Islamic groups have recently flourished across the country, some of which aim to promote the establishment of an Islamic Caliphate. ${ }^{24}$ One notable group is the largest radical Islamic group Hizb ut-Tahrir al-Islami (the Islamic Party of Liberation), which became active in the late 1990s and was banned in 1999 in light of its aim to establish an Islamic State. ${ }^{125}$

This increase of radical underground Islamic groups should be understood in light of the legitimation of the IRPT. As Karagiannis explains, the legalization of the IRPT and its participation in local and central government have ironically led to a decline in its popularity among the traditional supporters. ${ }^{126}$ In light of the IRPT's pragmatic views on social and economic problems and "low profile," it became hard to distinguish the IRPT from other secular parties. ${ }^{127}$ The ideological vacuum was then filled by other religious groups such as Hizb ut-Tahrir. ${ }^{128}$

Recent years demonstrate an increasing religious environment. "Since 2005, a course on the history of religions with a textbook on the history of Islam has been taught in public schools at the 10th grade level," and since 2009, "Tajikistan has a mandatory religious education in public schools." ${ }^{29}$ The preamble to the new 2009 law on religion recognizes the "special role of the Hanafi school of Islam

122. Id. at 457; see also Epkenhans, supra note 108, at 95.

123. Karagiannis, supra note 118 , at 14.

124. Aziz Niyazi, Islam and Tajikistan's Human and Ecological Crisis, in Civil Society in Central Asia 180, 189-90 (M. Holt Ruffin \& Daniel C. Waugh eds., 1999).

125. Karagiannis, supra note 118, at 1-5.

126. See id. at 2.

127. See id. at 17.

128. See id.

129. Robia Charles, Secular Regimes and State Engagement with RELIGION IN POST-SOviET EuRAsia 39 (2013) (unpublished Ph.D. dissertation, University of California, Berkeley), http://digitalassets.lib.berkeley.edu/etd/ucb/text/ Charles_berkeley_0028E_13144.pdf[https://perma.cc/8DYQ-5UQ2]. 
in the development of the national culture and moral life of the people of Tajikistan (The Hanafi school of Islam is a Sunni branch with which most citizens in the country identify)." "130 Such recognition has not appeared in any of the previous versions of Tajikistan's law on religion, and in fact Tajikistan became the first country in the region to recognize any form of Islam. ${ }^{131}$

Has the principle of secularism changed in Tajikistan? From a communist approach toward religion now, as Zainiddinov correctly notes, the state's attitude toward religion seems to be ambiguous. ${ }^{132}$

On the one hand, the state introduce[ed] a mandatory class on Islam . . . , holds international Islamic conferences, celebrates anniversaries of prominent Islamic scholars, allocates . . . land . . . for Saudi missionaries to build ... mosque[s], and [even] receive[d] the honored title of "The Islamic Culture Capital" for 2010. ${ }^{133}$

On the other hand, the state prohibits prayers at the workplace and prohibits the azaan (the call to prayer proclaimed five times a day) to be given by loudspeakers. ${ }^{134}$ Tajikistan is declared a secular state, and the secular nature of the state is deemed to be unamendable. Nonetheless, the principle of secularism has gone through some major changes as governmental power is shared with Islamic forces; and while restricting some religious practices, the state allows or even encourages religious independence which is developing to a widespread and enhanced Islamization process of the society. ${ }^{135}$

\section{Mali}

The story of secularism in Mali is fascinating. ${ }^{136}$ Independent Mali inherited the notion of secularism, or laïcité, from France, its

130. Id. at 43; see Robert C. Blitt \& W. Cole Durham, Analysis of the Republic of Tajikistan's Draft Law 'About Freedom of Conscience and Religious Unions', 26 U. TenN. C.L. Legal Stud. Res. PAPER SeRIES (2008) (analyzing early drafts of the 2009 law).

131. CHARLES, supra note 129 , at 43 .

132. Zainiddinov, supra note 98 , at 467.

133. Id.

134. Id.

135. See generally KHALID, supra note 101 (discussing the "Islamic Revival" in Central Asia, and how Central Asian states, after their independence, have resorted to similar methods the Soviet Union had applied to control and contain religion).

136. See Fatou Kiné Camara \& Abdourahmane Seck, Secularity and Freedom of Religion in Senegal: Between a Constitutional Rock and a Hard Reality, 2010 BYU L. REV. 859, 867-68 (2010) Arguably, the principle of secularity in Mali goes way back in history, to the Mali Empire, which covered most of West Africa. 
former colonial ruler, and declared itself in its 1960 Constitution a "secular" republic. ${ }^{137}$ Strangely enough, it appears that colonial rule in Mali actually intensified Islamization. As Alex Thurston describes it, the movement of people and ideas accelerated conversions to Islam, and as Mali transitioned to independence in 1960, it did so as a newly Muslim-majority country. ${ }^{138}$ In the first decades after independence, notwithstanding the state's efforts to marginalize Islamic activists, Islamic schools and mosques proliferated, and during the 1980s, state-sponsored Islamic institutions and unofficial Islamic groups emerged, altogether preparing the ground for a blossoming Islamic social life in the 1990s with about 150 Islamic associations. ${ }^{139}$

By the end of the 1980s, after a long period of hierarchical and centralized governance inherited from ancient kingdoms, French colonial administration, and post-independence military and oneparty regimes, people began expressing their anger with such autocratic precedents. ${ }^{140}$ In 1991, President Moussa Traoré was

The Charter of Kurukan Fuga, commonly known as the Constitution of the Empire of Mali, and designed by the empire's founder, Sundiata, in 1236 A.D. reflected a tradition of secularity and also respect toward both Islam and traditional religion. While the Charter recognized in Article 1 that "Muslim marabouts, or sufis, make up an essential part of society," it limited the role of Muslim leaders to teaching religions and states nothing about state affairs: "The five clans of marabouts are our teachers and our educators in Islam. Everyone has to hold them in respect and consideration." Id. (citing Charter of KuRUKAN FugA (CONSTITUTION OF THE EMPIRE OF MALI) art. 3).

137. See, e.g., Yuhniwo Ngenge, International Influences and the Design of Judicial Review Institutions in Francophone Africa, 61 AM. J. ComP. L. 433, 442 (2013) (demonstrating how French-speaking sub-Saharan African states borrowed from French constitutional and political traditions, while showing certain deviations from it).

138. Alex Thurston, Towards an "Islamic Republic of Mali?", 37 FLETCHER F. WORLD AFF. 45, 48 (2013) ("Under colonialism, more people moved from one place to another. They moved as refugees fleeing wars, freed slaves coming home, workers forced into labor, soldiers serving in the military, or traders operating in the colonial economy. . . . Changes sparked by colonialism disrupted pre-existing hierarchies of power, reshaping the social roles of the core groups within precolonial Muslim networks: merchants, clerics, and warrior-rulers. Individuals' conversions to Islam disrupted certain ethnic groups' claims to define the faith. Models of Muslim identity changed. Pressures grew to standardize worship practices throughout the Muslim community. . . By the waning years of colonial rule in the 1940s and 1950s, Muslims had a strong presence in Malian politics, economy, and society.").

139. Id. at 49-51.

140. Michael Bratton, Massa Coulibaly \& Fabiana Machado, Popular Views of the Legitimacy of the State in Mali, 36 CAN. J. AFR. STUD. 197, 198 (2002). 
overthrown by popular forces with the help of the military led by General Amadou Toumani Touré. General Touré presided over a year-long military-civilian transition, ending with a new Constitution. General Touré first established "The Transition Committee for the Salvation of the People," which quickly drafted the rules for political participation. ${ }^{141}$ The first decree issued by the Committee established freedom of association, whereas the second decree banned political parties that were based on religion. ${ }^{142}$ The new constitution of 1992 declares, in the Preamble, that the people of Mali "solemnly undertake to defend the republican and secular form of the state." ${ }^{143}$ Moreover, according to Article 25, "Mali shall be [a] . . . secular . . . Republic." ${ }^{144}$ Article 20 of the Constitution of the Republic of Mali states that "[p]ublic education shall be obligatory, free and secular." ${ }^{145}$ Article 28 stipulates that political parties must respect the secularity of the State. ${ }^{146}$ And, most importantly to our investigation, the Constitution of Mali includes in Article 118 a provision according to which "the secularity of the State . . shall not be the object of revision." ${ }^{147}$ This affirms the fundamental character of the principle of secularism.

Between 1992 and 2012, Mali had only two presidents. Alpha Oumar Konaré won the 1992 competitive election and was re-elected in 1997. Touré-returning from retirement-won the elections of 2002 and 2007. Throughout this time, Islamic associations acted as a pressure group and claimed an involvement in policy-making. After two decades of political liberalization and multi-party elections, expression of diverse Muslim identities was facilitated. Muslim activists, as I describe below, managed to influence and shape politics and values through mass movements and media. ${ }^{148}$ It is

141. Thurston, supra note 138 , at 50 .

142. See id.

143. See Constitution of the Republic of Mali, 1 Hum. RTs. L. Afr. 228, 228

(Christof Heyns, Hatem Ben Salam \& Umozurike Oji Umozurike eds., 1996).

144. Id. at 228 .

145. Id. at art. 229.

146. Id. at 230 .

147. Id. at 231; see also Julien Lacabanne, Les Principes Intangibles Dans la Constitution Malienne, FAIRE-SON-DrOIT 1, 9 (2015), https://www.academia.edu/ 29572505/Les_principes_intangibles_dans_la_Constitution_malienne_-_J._Lacabanne

(Fr.) (discussing the limitations on the revision power in Mali).

148. See Thurston, supra note 138, at 47; see also Julia Leininger, It's Institutions, Not Theology! Muslim Actors' Influence on Democratization in Mali, 9 PoL. \& RELIGION 815 (2016) (highlighting the relationship between religious actors and politics in Mali). 
therefore interesting to examine how a vibrant Muslim civil society and media, which provided Muslim activists opportunities to engage with politics, somehow coexisted with the "secular" nature of the state or challenged the meaning of secularism.

For example, when Mali was preparing for its 2002 presidential election, Muslim associations organized several mass rallies in which leaders of twenty Islamic associations from across the country met and urged voters to vote for candidates holding Islamic values.

The influence of Muslim activist civil society and its ability to act as a pressure group in the political arena can be demonstrated through the struggle surrounding the 2009 "Code of Persons and of the Family" (Code des personnes et de la famille). The reform of the family code was years in the making, during which numerous consultations with political parties and civil and religious organizations took place. The aim was to reform the Family Code to encourage more equality between the sexes and social justice for women. ${ }^{149}$ In 2009, after the adoption of the code, Muslim religious leaders and religious associations started to mobilize citizens to protest against the code on religious grounds. They organized a mass rally of about 50,000 people who protested in the streets of the capital, Bamako, against the family code because it contradicted the Sharia. President Touré suspended the Code and subjected it to revision. After taking Muslim leaders' concerns into account, a new modified version of the family code passed in 2011. This version preserved discrimination against women. In 2012, the High Islamic Council of Mali (HCIM) organized another mass rally urging the promulgation of the new code, which was indeed published a few days later. This demonstrates not only how much religious beliefs are prevalent in Malian "secular" society, but also the potential influence of certain religious streams and leaders on politics. ${ }^{150}$

The struggle over the family code provoked public debate and reflection about the role of Islam in politics and the nature of laïcité.

149. For understanding the efforts to reform the Family Code in Mali, see Dorothea E. Schulz, Political Factions, Ideological Fictions: The Controversy Over Family Law Reform in Democratic Mali, 10 Islamic L. \& Soc'y 132 (2003); see also Benjamin F. Soares, The Attempt to Reform Family Law in Mali, 49 DIE WeLT DES ISLAMS 398 (2009).

150. This section builds heavily on Thurston, supra note 138, at 50-53; see also André Moine, La Prise en Compte Internationale de la Nature du Pouvoir au Mali, 31 Civitas Europa 59, 64 (2013) (Fr.) (mentioning that even if secularism excludes in principle the intervention of clerics over political decisions, it has no effect on the influence of religion on popular convictions). 
In 2009, the President of the HCIM, Imam Mahmoud Dicko, stated that instead of regarding laïcité as "the negation of religion by the State," he prefers an approach of an "intelligent laïcité" in which "the rights of each are respected." 151 When asked about the implications of the HCIM's involvement in national affairs, Dicko replied, "We are not positioning ourselves politically, but we are positioning ourselves with respect to the interests of our country. We are in a country where we are [ninety-five percent] Muslims. . . . You think that we can remain indifferent to what happens to these people?" 152

Indeed, albeit the constitutional designation of the constitutional order as based on laïcité, Mali is a predominately Muslim country with over $90 \%$ of the population practicing some form of Islam. The possibility of a constitutional reform became "controversial in 2011 when, after years of 'expert examination' by the Constitutional Commission led by Daba Diawara," the President "announced that a constitutional referendum would be coupled with the April 2012 presidential elections." ${ }^{153}$ Drastic events that occurred in northern Mali in 2012, and have shaken the country since, brought issues of religious tolerance and the threat to secularism to the front.

In 2012, after several bloody confrontations with the army, a rebellion began with the Tuareg-led National Movement for the Liberation of the Awazad (MNLA), declaring Azawad's independence, making it an Islamic State. ${ }^{154}$ Therefore, more than a separatist rebellion, Islamic themes dominated the rebellion, as the

151. Thurston, supra note 138, at 52 (quoting Makmound Dicko, Président $d u$ Haut Counseil Islamique du Mali: 'C'est une Insulte pour notre pays,' LE RÉPUBLICAIN, Aug. 12, 2009, http://malijet.com/a la une du mali/16604-mahmoudou dicko_president_du_haut_conseil_islamique.html [https://perma.cc/X6WN-FHXK]).

152. Thurston, supra note 138, at 59 (quoting Charlotte Idrac, Mahmoud Dicko: 'Les Décisions Doivent Revenir aux Maliens', RFI, Aug. 9, 2012, http:// www.rfr/afrique/20120809-mahmoud-dicko-decisions-doivent-revenir-maliens [https:// perma.cc/8G8C-6B9S]); see also id. at 52 (explaining that in 2010, the SecretaryGeneral of the HCIM, Mohamed Kimbiri, stated that "the [true] secular state integrates religions into the conduct of public affairs." (quoting Tribune/Réplique de Mohamed Kimbiri à Me Bréhima Koné: 'Oui à un Etat laïc, non à un Etat Islamophobe', LE RÉPUBLICAIN (Dec. 6, 2010), http://www.maliweb.net/news/ contributions/2010/12/06/article,468.html [https://perma.cc/R6RZ-J9R6])); Martin van Vliet, Weak Legislatures, Failing MPs, and the Collapse of Democracy in Mali, 113 AFr. AfFAIrs 45, 63 (2014).

153. See Susanna D. Wing, 'Hands Off My Constitution': Constitutional Reform and the Workings of Democracy in Mali, 53 J. MoD. AFr. STUD. 451, 452 (2015).

154. See Thurston, supra note 138 , at 46 . 
MNLA was supported by several Islamist well-armed groups such as the Movement for the Uniqueness and the Jihad in West Africa (MUJAO), Al-Qaeda in Islamic Magreb (AQMI), Boko Haram (Nigeria), and the Islamist group Ansar al-Din (Defenders of the Faith), which together with its allies, controlled much of northern Mali. After the occupation of the entire north of the country up to Timbuktu and Gao, these jihadist movements expelled MNLA from the region and-opposing the secular nature of the state-they declared Sharia to be the fundamental law. The inability of the state institutions to control the situation led to a coup d'état that ended the regime of President Toumani Touré. A transitional government was put in place under African and international pressure, yet facing complete incapacity, the Islamic forces committed atrocities, and destroyed and vandalized administrative, religious, and cultural buildings. All this caused an international turmoil. Mali's interim President requested the French government and the Economic Community of West African States' urgent assistance. When Islamist forces pushed south into the Mopti region in early January 2013, French military, with a noteworthy backing of Chad and Niger, managed to re-conquer northern Mali and to stop the jihadist armies' advancement toward the capital. ${ }^{155}$

During the 2012-2013 crises, the religion-secularism tension was high. In August 2012, the transitional government created a Ministry of Religious Affairs, which had long been demanded by the HCIM. Since its creation there have been dialogues about the nature of the state and conditions for applying Sharia in the country, which threatens the "secular" nature of the state. ${ }^{156}$ For example, the Deputy Minister for Religious Affairs maintained that "Mali is a secular state connected with [the] religions." 157 According to this understanding, religious belief does not belong to the private sphere, but religion is involved in the functioning of state affairs. Likewise, Mahamoud Dicko, the abovementioned President of HCIM, has said that "[n]o

155. On the decline of both state authority and legitimacy in the run-up to the dramatic events that took place during the first months of 2012, see van Vliet, supra note 152 , at 63 .

156. Thurston, supra note 138 , at 60 .

157. Rokia Diabate, Laïcité du Mali en Péril: Le Ministre Délégué Chargé des Affaires Religieuses et le Président du Haut Conseil Islamique Font le Lobbying d'une République Islamique, MALIACTU (Jan. 23, 2014), http://maliactu.net/laicite-dumali-en-peril-le-ministre-delegue-charge-des-affaires-religieuses-et-le-president-du-hautconseil-islamique-font-le-lobbying-dune-republique-islamique/ [https://perma.cc/7XKHPEUF] (Fr.). 
article in the Malian Constitution prevents religions from meddling with politics." ${ }^{158}$ In July 2013, a new President was elected. Whilst maintaining secularism as a republic principle, the President began his inauguration speech with a long verse from the Koran. ${ }^{159}$

On the other hand, when conditions for opening a dialogue between the Transitional Government and rebel groups in northern Mali were dictated, respect for the territorial integrity of the country and the secular nature of the state were selected. ${ }^{160}$ The Ouagadougou Agreement of 18 June 2013 contains provisions to this effect. The parties not only declared "their attachment to the Constitution of the Republic of Mali of 25 February 1992" and thus to the principle of secularism contained therein, but they also specifically agreed, in the preamble, to respect " $[\mathrm{t}]$ he secularism of Mali."161 As negotiations continued, these principles remained unaltered. Notwithstanding the demands for the creation of an Islamic Republic of Mali, there was a strong stand, even on the part of several leading imams, for secularism. ${ }^{162}$ Therefore, even in the midst of the crisis, Malian officials made it very clear that certain constitutional principles were non-negotiable; namely, the secular nature of the state. ${ }^{163}$ Religious authorities, Susanna Wing emphasizes, had an important role to play in the fight against radical Islamist groups in the North. ${ }^{164}$

158. See id.

159. Secularism at Risk in Sub-Saharan Secular States: the Challenges for Senegal and Mali, Open Democracy (Oct. 10, 2014), https://www.opendemocracy. net/5050/fatou-sow/secularism-at-risk-in-subsaharan-secular-states-challenges-forsenegal-and-mali [https://perma.cc/RP73-N3E5].

160. See U.N. Secretary General, Report on the Situation in Mali, 1 10, U.N. Doc. S/2013/189 (Mar. 26, 2013).

161. ACCORD DE OUADADOUGOU (Fr.), http://news.abamako.com/documents/ docs/AccorddeOuagadougou.pdf [https://perma.cc/3LVM-8GXT] (last visited Apr. 21, 2017).

162. Wing, supra note 153, at 469.

163. See Lamine Diallo, Le Ministres des Affaires Étrangères a Propos de la Crise au Nnord: "L'intégrité Territoriale, la Laïcité et le Caractère Républicain du Mali ne sont pas Négociables", MALiWeB (Nov. 8, 2012) (Fr.), http:// www.maliweb.net/ la-situation-politique-et-securitaire-au-nord/le-ministres-des-affairesetrangeres-a-propos-de-la-crise-au-nord-lintegrite-territoriale-la-laicite-et-le-caractererepublicain-du-mali-ne-sont-pas-negociables-103613.html [https://perma.cc/6EP2WWSS]; see also Adam Nossiter, Rebels in North Mali Sign Peace Deal Allowing in Government Troops, N.Y. Times (June 18, 2013), http://www.nytimes.com/2013/06/ 19/world/africa/mali-and-rebels-reach-peace-deal.html [https://perma.cc/JB7Y-M8BK]; Wing, supra note 153, at 469.

164. Wing, supra note 153, at 469. 
Of course, notwithstanding this alleged "non-negotiability," the spread of militant Islamic groups; the application of Sharia criminal penalties; the increase of religious schools, associations, and mosques; the active participation of Muslim religious leaders and organizations in political debates and their influence thereof; and the general prominence of religion in the public sphere, also had their own dynamics, which seemed to many as if Mali was shifting away from the principle of laïcité enshrined in the Malian Constitution. The question exists: Can the secularism barrier resist the thrusts of those Islamic powers that advocate for a direct intervention in politics? ${ }^{165}$

So where does Mali go? A recent policy paper demonstrates how several Malian politicians and religious leaders are critical about the French interpretation of the secularity principle, which they see as anti-religious, rather than as a guarantee of religious freedom: ${ }^{166}$

They emphasize that the principle of "laïcité" should entail respect of religious diversity, equal treatment by the state of different religious groups[,] . . . and the right of each individual to practice their religion [even] in the public sphere.

Based on interviews with religious leaders and politicians in Mali, this report briefly explores aspects of Islam as a political force in Mali [and] the different understandings of the concept of laïcité among Malians ... [The report] argue[s] that [in Mali:]

[R]ather than a shift from a "secular" to an "Islamist" state, the concept of "laïcité" is undergoing renegotiation. This entails, firstly, a renegotiation of the principle of religiously "neutral" governance. Many Malian Muslims in the urban elite emphasize that Islam is a democratic religion .... and retain the right to express political arguments based on Muslim values. ... [M] any of the defenders of the right to express political views with reference to Muslim values stress the equal right of all citizens to participate in political debate and to hold office. In effect, this renegotiation of religiously "neutral" governance entails an increased emphasis on religious pluralism, rather than an insistence upon the "absence" of religious affairs in governance. This reassertion of religious freedom is simultaneously a defense against "federalism" and an increased autonomy of the northern areas, and thus, the protection of the territorial integrity of Malian nationhood.

Moreover, the secularity of the state is defended in the sense that the separation between the state and religious institutions is maintained: State religion does not have strong defendants among politicians in Bamako,

165. See Moine, supra note 150 , at 61 .

166. Tone Sommerfelt \& Kristin Jesnes, 'Laḯcité' in Southern Mali: Current Public Discussions on Secularism and Religious Freedom 9 (2015), https://www.fafo.no/images/pub/2015/20410.pdf [https://perma.cc/N6JY-E99R]. 
and religious organizations are not under direct state control. However, the tolerance for political standpoints based on religious values is rising, especially in debates over family law and gender politics. Several prominent Muslim leaders develop explicit political agendas and they debate, in public, where the religious sphere ends and the political sphere begins. . . In this sense, they challenge the strict, French version of secularism as "laïcité", and its colonial legacy.

Secondly, renegotiation of "laïcité" also takes the form of increased government involvement in and control over religious affairs. In an effort to distance Mali from extremist Islam, and in response to the advances of extremist Salafist groups in northern Mali, the state is seeking to control religious groupings, for instance by establishing guidelines for religious leadership, preachers and education. This increased state participation in the religious domain further accentuates the visibility of religious issues in public debate. $^{167}$

The report's findings and conclusion seem to suggest that the principle of secularism in Mali, although "eternal", is still negotiable.

\section{B. On the Negotiability of "Eternal" Principles}

\section{Non-self-entrenched Eternity Clauses}

Most of the world's eternity clauses establish the unamendability of certain constitutional principles, but they are themselves not self-entrenched. ${ }^{168}$ If such an un-entrenched provision protects the principle of secularism from revisions, can the unamendable provision itself be amended? Theoretically, there are several approaches for resolving the challenge posed by eternity clauses that are not self-entrenched. ${ }^{169}$ According to the first approach, if an eternity clause is not self-entrenched, then the protected eternal principles may be amended in a double amendment procedure; in the first step, the eternity clause is itself repealed (an act that is not in itself prohibited), and in the second step, the previously-but no longer-protected principle is revised or

167. See id. at 9-10.

168. See Jon Elster, Ulysses Unbound: Studies in Rationality, PreCommitment, AND CONSTRAINTS 101-02 (2000).

169. I have written about this earlier in Yaniv Roznai, Amending 'Unamendable' Provisions, Constitution-MAKIng AND Constitutional CHANGE BLOG (Oct. 20, 2014), http://constitutional-change.com/amending-unamendableprovisions/ [https://perma.cc/PGP7-Z2FS]. On this dilemma, see also Richard Albert, Amending Constitutional Amendment Rules, 13 INT'L J. CONST. L. 655, 66264 (2015). 
abolished. ${ }^{170}$ I have previously argued for a different approach, which seeks to provide eternity clauses a purposive interpretation according to which even if they are not self-entrenched, they should be regarded as such; otherwise the use of eternity provisions is almost meaningless. ${ }^{171}$ Paraphrasing Georges Liet-Veaux's La "Fraude a la Constitution", ${ }^{172}$ I argued that from a substantive or purposive perspective, the double-amendment procedure should be regarded as "fraud upon the constitution" because "what cannot be done directly cannot be done indirectly." 173 If my claim for the implicit entrenchment of eternity clauses is not accepted, then surely even eternal principles such as secularism can simply be revised; either in a double-amendment procedure or perhaps even in a single procedure. ${ }^{174}$

This is what occurred in Portugal. Recall, Article 288 of the Portuguese Constitution of 1976 explicitly placed the separation between state and church beyond the amendment power, alongside other principles. ${ }^{175}$ In 1989, Article 288 was itself amended, and the

170. See the debates in Laurence H. Tribe, American Constitutional LAW 111-14 (3d ed. 2000); see also Virgílio Afonso da Silva, A Fossilised Constitution?, 17 RATIO JuRIS 454, 456-57 (2004); Eivind Smith, Old and Protected? On the "Supra-Constitutional" Clause in the Constitution of Norway, 44(3) IsR. L. REV. 369, 375 (2011).

171. See RozNAI, supra note 11 , at $142-43$. For a similar claim, see Jason Mazzone, Unamendments, 90 IowA L. REV. 1747, 1818 (2005).

172. Georges Liet-Veaux, La 'Fraude a la Constitution': Essai d'une Analyse Juridique des Révolutions Communautaires Récentes: Italie, Allemange, France, 59 Revue Du Droit Et De Science Politique En Fr. Et A L’etranger 116 (1943) (Fr.).

173. RozNAI, supra note 11, at 140. See Cummings v. Missouri, 71 U.S. 277, 325 (1866). On this maxim, see generally D.K. Singh, "What Cannot Be Done Directly Cannot Be Done Indirectly": Its Meaning and Logical Status in Constitutionalism, 29 MoD. L. REV. 273 (1966).

174. Douglas Linder, for example, argued that there is no need for a twostage process, as the unamendable provision and the protected subject could both be repealed in the same act since the outcome is similar. See Douglas Linder, What in the Constitution Cannot Be Amended?, 23 ArIz. L. Rev. 717, 729 (1981).

175. Constitution of the Portuguese Republic Apr. 2, 1976, art. 290 (amended in 1989 to article 288) (subsequently amended 2005):

Material limits to revision

1. Laws revising the Constitution shall not detract from:

a. national independence and the unity of the state;

b. the republican form of government;

c. the separation of the churches from the state;

d. the rights, freedoms and safeguards of citizens;

e. the rights of workers, workers' committees and trade unions; 
protected principle of collective ownership of means of production was omitted, in order to open the economic system to a larger movement of privatization, which was necessary after Portugal's entry to the European Community in 1986. ${ }^{176}$ This controversial amendment was never challenged before the Constitutional Court. ${ }^{177}$ Accordingly, if one principle that is part of the "material limit" to revision can be amended, then arguably other principles, such as "the separation of the churches from the state," can similarly be amended. ${ }^{178}$

Although different, the 2005 Togo crisis yields a similar conclusion. The 1992 Constitution of Togo includes a constitutional revision procedure in Article 144. ${ }^{179}$ It also includes certain

f. the principle of collectivisation of the main means of production and land and of natural resources and the abolition of monopolies and large estates;

g. the democratic planning of the economy;

$\mathrm{h}$. the appointment of the elected members of the organs of supreme authority, the organs of the autonomous regions and the organs of local government by direct, secret and regular universal suffrage and the system of proportional representation;

i. plurality of expression and of political organisation, including political parties, and the right of democratic opposition;

j participation by local people's organisations in local government;

$\mathrm{k}$. the separation and interdependence of the organs of supreme authority;

1. the scrutiny of legal provisions for active unconstitutionality and unconstitutionality by omission;

$\mathrm{m}$. the independence of the courts;

n. the autonomy of local authorities;

o. the political and administrative autonomy of archipelagos of the Azores and Madeira.

Id.

176. See Jorge Bacelar Gouveia, Constitutional Law in Portugal 22 (2011). On this amendment, see also Víctor Ferreres Comella, Constitutional Courts and Democratic Values: A European Perspective 207 n.39 (2009); Jónatas E.M. Machado, The Portuguese Constitution of 1976: Half-life and Decay, in Engineering Constitutional Change: A Comparative Perspective on EUROPE, CANADA AND THE USA, supra note 54, at 273, 286-97.

177. See Paulo Ferreira da Cunha, Constitutional Sociology and Politics: Theories and Memories, 5 Silesian J. Legal Stud. 11, 25 (2013) (noting that this amendment "has always shocked us because it undermines the standard meaning and thus causes the Constitution to lose all of its enforceability").

178. See id.

179. Togo CONSTITUTION OF 1992, art. 144 ("The initiative of revision of the Constitution belongs concurrently to the President of the Republic and to one-fifth $(1 / 5)$ at least of the deputies composing the National Assembly. The bill or the proposal of revision is considered as adopted if it is voted with the majority of fourfifths (4/5) of the deputies composing the National Assembly. In default this 
circumstantial limits to constitutional amendments: "No procedure of revision may be engaged or pursued in a period of interim or of vacancy or when the integrity of the territory is infringed." 180

On February 5, 2005, Gnassingbé Eyadéma, Togo's President since 1967, died. Stephen Schnably describes the events that followed: "Within hours, the military declared his son Faure Gnassingbé the new president. Article 65 of Togo's Constitution, however, provided that if the president died, the Speaker of the [National Assembly] was to exercise the functions of the presidency for sixty days," during which elections would be held. ${ }^{181}$ In light of this constitutional rule, Fauré Gnassingbé's accession was regarded by the African Union (AU), the Economic Community of West African States, and France (Togo's former colonial ruler) as a blatant and unacceptable violation of the Togolese Constitution. Eyadéma's son's accession was regarded as either the initiation of a family dynasty or the effort by the military to rule from behind the scenes, or both. ${ }^{182}$ The government justified the accession based on wide and inherent emergency powers. The military claimed that because the speaker was absent from the country at the moment the president died (he was in Paris), a power vacuum was created that called for swift action to ensure stability and order.

One difficulty with this claim is that by announcing the suspension of the constitution and closing the country's borders, the military prevented the Speaker's return. In light of the increasing external pressure, Fauré Gnassingbé resigned and was immediately elected (on February 6) by the Togolese National Assembly as the new speaker, a position that made him eligible to exercise the President's powers for sixty days. Then, by unanimous vote, the

majority, the bill or proposal of revision adopted with the majority of two-thirds $(2 / 3)$ of the deputies composing the National Assembly, is submitted to referendum. The President of the Republic may submit to referendum any bill of constitutional law.").

180. Id. Circumstantial limits to constitutional amendments are those constitutional provisions that specify the circumstantial dimension in which constitutional amendments are prohibited. See Kemal Gözler, Le Pouvoir DE RÉVISION CONSTITUTIONNELle 122-23 (1997) (Fr.); Yaniv Roznai \& Richard Albert, Limitations on Constitutional Amendment in Emergencies (unpublished manuscript, 2017) (on file with author).

181. See Stephen J. Schnably, The OAS and Constitutionalism: Lessons from Recent West African Experience, 33 SyRAcuse J. InT'L L. \& COM. 263, 267 (2005).

182. For a review of the events, see $i d$; Stephen J. Schnably, Emerging International Law Constraints on Constitutional Structure and Revision: A Preliminary Appraisal, 62 U. MiAmi L. REV. 417, 474 (2008). 
National Assembly also exercised its constitutional amendment power under Article 144 to revise the constitution, modifying Article 65 in order to allow the son to serve out the remainder of his father's term in the case of a vacancy. Fauré Gnassingbé was sworn in the next day. The AU strongly condemned this constitutional revision that was made in violation of the relevant provisions of the Togolese Constitution and suspended Togo's participation in the organization. ${ }^{183}$ Schnably notes that "there was ample ground in Article 144 to question the amendments' validity. Article 144 provides that amendments may not be adopted when the presidency is vacant ... The presidency may well have been vacant on February 6, when the legislature adopted the amendments." ${ }^{84}$ However, the Togolese National Assembly took the position that a constitutional limitation on the amendment power might itself be amended out of existence. Therefore, at the same time it elected Fauré Gnassingbé as Speaker and amended Article 65, the Togolese legislature also amended Article 144 to remove the prohibition on amending the constitution when the presidency was vacant. ${ }^{185}$ After pressure from the AU and the Economic Community of West African States, Togo backed down; "On February 21, [2005], the National Assembly amended the constitution yet again to provide for elections within sixty days, essentially reversing the previous amendments." ${ }^{186}$ Four days later, Fauré Gnassingbé resigned, a move that paved the way for a new Speaker and Interim President, Bonfoh Abass. ${ }^{187}$

The point here is not to emphasize the role of international community when it comes to domestic constitutional reforms, ${ }^{188}$ but

183. Schnably, supra note 181 , at 269.

184. Id. at 269-70.

185. Loi 2005-002 du 6 février 2005 portant modification des articles 65 et 144 de la Constitution [Law 2005-002 of Feb. 6, 2005 amending Articles 65 and 144 of the Constitution], J. Officiel De LA Republique Togolaise, Feb. 6, 2005 (removing reference to vacancy of the presidency) (Fr.); see also Schnably, supra note 181 , at 270 .

186. Schnably, supra note 181, at 270; Loi 2005-006 du 24 février 2005 modifiant les articles 65 et 144 de la Constitution [Law 2005-006 of Feb. 24, 2005 amending articles 65 and 144 of the Constitution], J. OfFiciel DE LA REPubliQue Togolaise, Feb. 24, 2005 (restoring the Togolese Constitution, arts. 65 and 144, to its former text) (Fr.).

187. See Schnably, supra note 181, at 270.

188. On this, and with a special reference to the 2005 crisis in Togo, see Schnably, supra note 182, at 474-78. More generally, on international and supranational limitations on constitutional amendments, see Yaniv Roznai, The Theory and Practice of 'Supra-Constitutional' Limits on Constitutional Amendments, 62 INT’L \& COMP. L.Q. 557 (2013). 
to focus on the ability to amend Article 144 itself. This is important because as aforementioned, Article 144 includes a material limit to constitutional change according to which the secularity of the state cannot be revised. ${ }^{189}$ True, the amendments at issue in the 2005 crisis did not address the issue of the secular form of government. However, it demonstrates how easily the article imposing limitations on constitutional change may itself be amended in the future.

\section{Fifty Shades of Secularism ${ }^{190}$}

Apart from the possibility of revising the eternity clause itself, as described in the previous section, I wish to argue that even if the eternity provision remains intact, the meaning of the protect principle may change. Accordingly, the mere unamendability of secularism does not mean that it is non-negotiable. ${ }^{191}$ When secularism is protected in the constitution as an eternal principle, what is being protected is a constitutional principle, not a rule. Rules demand strict compliance and apply in an all-or-nothing fashion. Principles, in contrast, are more generalized guidelines, permit balancing, and may be realized in various degrees. The protection of a general constitutional principle such as secularism is a flexible protection because the elasticity and the semantic openness of these terms allow their content to evolve and change along social changes. The protected principle of secularism can be interpreted, reinterpreted, and shaped through time, practice, and legislation. ${ }^{192}$

In his excellent book on secularism in India, Gary Jacobsohn wrote, "Now, secularism may very well be an immutable principle,

189. Togo Constitution of 1992, art. 144.

190. I borrow the use of "50 shades of secularism" from Hillel Sommer, The Canadian Override Mechanism: A "Bête Noire"? A White Knight? Designing 50 Shades of Grey, presented at a symposium titled The Constitution of Canada: History, Evolution, Influence, and Reform (May 24, 2017).

191. Cf. Rosenfeld, supra note 70, at 88 ("[I]deological secularism's amenability to partial conversion on matters of utmost importance to its way of life suggests that it is open to significant accommodation of competing conceptions of the good."). Rosenfeld here refers to "amendability", but in the case of unamendability, it would mean negotiability.

192. See Dieter Conrad, Basic Structure of the Constitution and Constitutional Principles, in LAW \& Justice-An AnThology 186, 194 (Soli J. Sorabjee ed., 2003); RozNAI, supra note 11, at 215-16. On rules and principles more generally, see Robert Alexy, On the Structure of Legal Principles, 13 RATIO JURIS. 294, 295 (2000), and Ronald M. Dworkin, The Model of Rules, 35 U. CHI. L. REv. 14, 25 (1967). 
but what . . . is secularism?" 193 As Justice Reddy admitted in the Bommai case in which the principle of secularism was recognized as a part of the constitution's basic structure, secularism by itself is "not capable of precise definition." 194 Indeed, there is no single clear definition of secularism. Of course, in general, secularism "involves organizations and legal constructs that reflect the institutional expressions of the secular in a nation's political realm and public life." ${ }^{195}$ More specifically, "[I]n secular regimes, sovereignty belongs to the nation and not to a divine body," the state is separate from religion, the government is neutral toward all religions, and the education and legal systems are secular. ${ }^{196}$

But there may be various approaches to secularism. ${ }^{197}$ Secularism, even as an ideology that challenges religion in the political and social arena, is not monolithic, but, as Jonathan Fox notes, "[T]here are clearly divisions and competition within . . . the secular and religious camps." ${ }^{198}$ For example, one can have a militant or fundamentalist understanding of secularism (something along the lines we often see in France and Turkey), which assumes that religion is only a private issue and that outer manifestations of religion cannot have any place within the public realm. In these places, secularism is not merely the separation of religion and politics, but a clear rejection of and active opposition to manifestations of religiosity in the public sphere. However, secularism need not necessarily be "hostile" toward religions, but it merely means that the state does not officially recognize any one religion. ${ }^{199}$ According to Bhikhu Parekh:

193. JACOBSOHN, supra note 59, at 159.

194. S. R. Bommai v. Union of India (1994) 3 SCC 1, 15 (India); JACOBSOHN, supra note 59, at 153.

195. Barry A. Kosmin, Contemporary Secularity and Secularism, in Secularism \& Secularity: Contemporary International Perspectives 1 (Barry A. Kosmin \& Ariela Keysar eds., 2007).

196. Adrien Katherine Wing \& Ozan O. Varol, Is Secularism Possible in a Majority-Muslim Country?: The Turkish Example, 42 TEX. INT'L L.J. 1, 5-6 (2006).

197. On the divergent interpretations of laicism see, e.g., René Rémond, La Laïcité et ses Contraires, 75 Pouvorrs 7, 7-16 (1995) (Fr.).

198. Jonathan Fox, Political Secularism, Religion, and the State 17 (2015).

199. Compare Leszek Lech Garlicki, Perspectives on Freedom of Conscience and Religion in the Jurisprudence of Constitutional Courts, 2001 BYU L. REV. 467, 472-73 (2001) (stating the premise of the separation of church and state is based on neutrality toward religion, not hostility), with Zorach v. Clauson, 343 U.S. 306, 314 (1952) (stating, "We find no constitutional requirement which makes 
The secularist thesis can take several forms of which two are the most common. In its weaker version it separates state and religion and maintains that the state should not enforce, institutionalize or formally endorse a religion . . . and should in general retain an attitude of strict indifference to religion. In its stronger version it also separates politics and religion and maintains that political debate and deliberation should be conducted in terms of secular reasons alone. ${ }^{200}$

Therefore, there is a spectrum of secularism between militant secularism and secular states that acknowledge a state church. As for the latter, Jacobsohn gives the example of Sweden, which "had an established Church, but that legal designation hardly disqualifies [it] from asserting its secular credentials." 201 There are "mild" or "soft" versions of secularism, in which the separation of state and religion, privatization of religion, and differentiation between religious and non-religious spheres, are not fully and strongly implemented because religion is always present there and cannot easily be abandoned. ${ }^{202}$ In other words, there are various degrees of secularity. ${ }^{203}$ Lech Garlicki writes that:

it necessary for the government to be hostile to religion and to throw its weight against efforts to widen the effective scope of religious influence.").

200. Bhikhu Parekh, Rethinking Multiculturalism: Cultural Diversity AND POLITICAL THEORY 322 (2000).

201. JACOBSOHN, supra note 59, at 30. The Church enjoyed a special constitutional status for many decades until recently when it was disestablished, at least in major part. See E. Kenneth Stegeby, An Analysis of the Impending Disestablishment of the Church of Sweden, 1999 BYU L. REV. 703, 704 (1999); see generally C. Carlson, Excessive Entanglement of Church and State: Applying the Lemon Test to the Disestablishment of the Church of Sweden, 21 N.Y. L. ScH. J. INT'L \& COMP. L. 593, 593-612 (2002). Of course, there are democratic countries that provide for the existence of a "state church" or an "official religion." One may mention the CONSTITUTION OF DENMARK 1953, art. 4 provides that: "The Evangelical Lutheran Church shall be the Established Church of Denmark, and, as such, it shall be supported by the State." See also Constitution OF NORWAY 1992, art. 2 ("The Evangelical-Lutheran religion shall remain the official religion of the State. The inhabitants professing it are bound to bring up their children in the same.").

202. Ahmet Kuru distinguishes between assertive secularism, which requires the state to play an assertive role in excluding religion from the public sphere (such as in France or Turkey) and passive secularism, which requires the state to be passive and allow public visibility of religion (such as in the U.S.). AHMET T. KURU, Secularism and State Policies Toward Religion: The United States, France, AND TURKEY 11- 12 (2009).

203. See Jeroen Temperman, The Neutral State: Optional or Necessary?: A Triangular Analysis of State-Religion Relationships, Democratisation and Human Rights Compliance, 1 ReLigion \& HuM. RTs. 269, 269-70 (2006) (describing these degrees as "[i]ntermediate forms of state-religion affiliation"). 
[T] he principal of separation of church and state is considered not only as admitting, but even as assuming, some cooperation between church and state. Even the definition of the state as "secular" is not contradictory to it: "The Constitution does not foresee any cooperation between the state and religious communities. Nevertheless, the state shall not ignore religion."204

Garlicki provides the example of Switzerland, where "some cantons . . . have introduced the concept of separation of church and state, but in 1980, a popular referendum to implement complete separation of church and state was rejected." 205

Returning to the example of Portugal, which as aforementioned, provides an eternal protection for the separation between state and church in Article 288(c) of the Constitution, in other words, "[t]he separation between Church and State" is a substantive limit to constitutional revision. ${ }^{206}$ There are other constitutional provisions that reinforce this separation. Article 41(4) provides that "[c]hurches and other religious communities shall be separate from the state and free to organise themselves and to perform their ceremonies and their worship." ${ }^{207}$ Article 43(2) and (3) prohibits the state to program education "in accordance with ... religious directives" and excludes any link between "public education" and a religious belief. ${ }^{208}$ Moreover, according to Articles 51(3) and 55(4), political parties "may not employ names that contain expressions which are directly related to any religion or church, or emblems that can be confused with national or religious symbols," and trade unions must be "independent of . . . religious denominations." ${ }^{209}$ Article 53 provides that "[t]he churches and religious communities are separate from the State and free to organize and exercise their own ceremonies and worship." ${ }^{210}$ The Portuguese constitution establishes laicite in the form of a separation of church and state, but not laicisme, i.e., "a hostile implementation

204. Garlicki, supra note 199, at 477-78.

205. Id. at 477.

206. See supra Section I.A; Constitution of the Portuguese Republic 2005, pt. IV, tit. II, art. 288(c).

207. Constitution of the Portuguese Republic 2005, pt. IV, tit. II, ch. I, art. 41(4).

208. Id. at pt. I, tit. II, ch. I, art. 43(2)-(3).

209. Id. at pt. I, tit. II, ch. II, art. 51(3); id. pt. I, tit. II, ch. III, art. 55(4).

210. Alejandro Saiz Arnaiz et al., Directorate General for Internal Policies: Religious Practice and Observance in the EU Member States, EUR. PAR. Doc., 29 n.19 (2013), http:/www.europarl.europa.eu/RegData/etudes/etudes/join/2013/474399/ IPOL-LIBE_ET(2013)474399_EN.pdf[https://perma.cc/4NQB-RKQU]. 
of this separation." ${ }^{211}$ In a decision of the Portuguese Constitutional Court from 1987, it was held "that the state obligation is not only to allow the operation of particular religions[,] but that the state is obliged to cooperate with such religions as 'religious needs have become a legally recognized right that the state must ensure." ${ }^{\prime 212}$ In the words of Garlicki, "Non-identification and neutrality assume separation of church and state, but generally the separation is not an absolute one." 213

The rejection of an absolute separation is also visible in Italy, another state in which the principle of secularism is considered an unamendable principle (although implicitly and not explicitly). ${ }^{214}$ According to the Italian Corte Costituzionale, the principle of secularism implies to pay attention for religions that are not the dominant one and not to favor the majority's religion. ${ }^{215}$ This approach, as Francesca Astengo suggests, distances itself both from total indifference to religions and from the laicité à la française, which postulates religion's explicit exclusion from the public sphere. ${ }^{216}$ The flexible nature of secularism, even when protected as an eternal principle, is evident from the three case studies conducted above. In Mali, it appears that the concept of laicité has undergone renegotiation, as the tolerance for political viewpoints based on religious values is rising, and as prominent Muslim leaders advance political agendas and debate them in the public sphere, both evident in the debates over the family code. ${ }^{217}$

In Tajikistan, on the one hand, the unamendability of secularism managed to moderate the Islamic political party that seeks to "play according to the rules of the game" and within the constitutional order's super-protection of secularism. This seems to be in accordance with Hakan Yavuz's contention that

211. Garlicki, supra note 199, at 477.

212. Id. at 478 .

213. Id. at 476 .

214. See supra Section I.B.

215. See Astengo, supra note 47, at 17.

216. See id. at 17-18 n.10. See Faraguna, supra note 51, for a discussion on the changing nature of secularism through Italian history, and the tension between the 'written constitution' and the 'living constitution.' Faraguna demonstrates how, paradoxically, the Italian Monarchical Constitution of 1848 designated Italy as a confessional State, yet an enquiry into law-in-practice or the 'living constitution' reveals a clear secular attitude of the state until 1929 when it became more in line with the formal constitution. See id.

217. See supra Subsection II.A.3. 
radical religious groups moderate their practices and ideologies when they enter into a competitive and rule-based participatory political system. . . . This process . . . allows the log-jam between polarized secular and religious forces to be broken discursively, as each side is now able to engage directly with the other along multiple channels of interaction in political and public spheres. ... ${ }^{218}$

On the other hand, the forcible elimination of religion from Tajikistani society has led to the formation of radical Islamic groups. From the religion's perspective, Islam is a necessary element of society, which was artificially separate from the state. ${ }^{219}$ The increasing religious environment, constitutional changes that have allowed participation of religious parties, and the legal recognition of the "special role of the Hanafi school of Islam" in the life of Tajikistan people all suggest that the secular nature of the state has been somewhat renegotiated. ${ }^{220}$

A change in the secular nature of the state also occurred in Turkey, notwithstanding the eternal protection of secularism in the constitution. The strong protection granted to the enshrined principle of secularism by the Constitutional Court, as evident in the struggle over the headscarf ban in universities, was eventually circumvented by the government by means of administrative tools, rather than major constitutional modifications. The eternal principle of secularism in Turkey need not be interpreted as unchangeable. See the claim of Svetlana Tyulkina:

The idea of secularism, which is being shielded from any public debate, was introduced into Turkish society in the $1920 \mathrm{~s}$. . . . [I]t is apparent that the political situation has changed considerably since then and that the Ataturk reforms and ideas should now be interpreted in a way that better suits the current time. I do not argue that Turkey should abandon the principle of secularism altogether and thereby allow religion to flow immediately into the public sphere. Rather I would argue that it is time to reconsider the ideas introduces some 100 years ago to see if they are still compatible with major democratic principles accepted by society. ${ }^{221}$

Indeed, even within Turkey one can find today different opinions with regard to the meaning of secularism. ${ }^{222}$ Examining

218. YAVUZ, supra note 71, at ix.

219. Ro'i, supra note 120, at 102.

220. See supra Subsection II.A.2 (citing ChARLES, supra note 129, at 43).

221. TYULKINA, supra note 81, at 181.

222. See YAVUZ, supra note 71 , at 153-59 (describes three modes of secularism in Turkey); Christopher Houston, Militant Laicists, Muslim Democrats, and Liberal Secularists: Contending Visions of Secularism in Turkey, in MusLiM Secular Democracy 253, 254 (Lily Zubaidah Rahim ed., 2013). 
variations of laïcité in France, Turkey, and Senegal, Ahmet Kuru and Alfred Stepan have recently demonstrated "that not only secularism in general, but also laïcité, a particular conception of secularism with a historical and normative background, has multiple interpretations." 223 Amelie Barras summarizes the notion that secularism, as a constitutional principle, "shifts, gets (re)articulated and transformed with time and contexts;", 224 even when it is eternal, it is not unchangeable.

\section{Volksgeist and Constitutional Unamendability}

It is interesting to note that the eternal constitutional entrenchment of secularism exists in states with large religious populations. Notwithstanding the constitutional protection of the separation of the churches from the state in the Portuguese Constitution, Portugal is perceived by many as a traditional Catholic society, and the vast majority of the population, $85 \%$, identifies itself as Catholic. ${ }^{225}$ Guinea, to take another example, is a predominantly Islamic country, with Muslims representing $85 \%$ of the population, ${ }^{226}$ yet the constitution of 2010 stipulates in Article 154 that "the principle of secularity [laïcité] . . . may not be the object of a revision." 227 In fact, 140 million Muslims, i.e., about $13.5 \%$ of the 1 billion Muslims living in predominantly Muslim countries, live in eleven predominantly Muslim countries, the constitutions of which proclaim the state to be secular. ${ }^{228}$ This is especially interesting because, as Garlicki notes, "Islam, from its very origins, has been

223. Kuru \& Stepan, supra note 97, at 115.

224. AmÉlie Barras, Refashioning Secularisms in France and Turkey: The CASE OF THE HEAdSCARF BAN 10 (2014) (documenting how, in both France and Turkey, activists have contested bans on headscarves, arguing that it is possible to believe in the values conveyed by secularism and simultaneously to remain devoted to a religious faith, thereby revisiting secularism to craft a space for their religiosity).

225. Ricardo Alves, Secularism and Secularization in Portugal, RePúBlica E LAICIDADE 1, 3 (Nov. 26, 2010), http://www.laicidade.org/wp-content/uploads/2011/ 01/Secularism-and-Secularization.pdf [https://perma.cc/6PKT-K42W].

226. See Tad Stahnke \& Robert C. Blitt, The Religion-State Relationship and the Right to Freedom of Religion or Belief: A Comparative Textual Analysis of the Constitutions of Predominantly Muslim Countries, 5 InT'L J. CIV. SoC'Y L. 43, 81 (2007).

227. COnStitution FOR the Republic of Guinea 2010, tit. XVII, art. 154.

228. See Stahnke \& Blitt, supra note 226, at 47. The Muslim countries are Burkina Faso, Chad, Guinea, Mali, Niger, Senegal, Azerbaijan, Kyrgyzstan, Tajikistan, Turkey, and Turkmenistan. Id. 
aligned with the state; in this tradition, the identity of religion and government has always been one of Islam's fundamental features." 229

In all of the three case studies conducted, there is a dominant religion. In Turkey, where the state is described as secular-a unamendable principle, about $98 \%$ of the population is Muslim. ${ }^{230}$ Russell Powell, who has empirically studied Turkish perceptions of law and religion, argues that "Turkey is a very religious country in that polling consistently indicates that a significant majority of Turks identify as religious. ... [I]t would be wrong to underestimate the role of religion in the formation of Turkish legal norms and citizens' understanding of those norms." 231 His empirical research demonstrates a trend of increasing support for Sharia within Turkey. ${ }^{232}$ In Tajikistan, $97 \%$ of the Tajikistani population is Muslim, and an estimated $30-40 \%$ of the rural population and $5-10 \%$ of the urban population regularly follow Muslim practices or attend mosques. ${ }^{233}$ And, in Malian society, at least $90 \%$ of the people identify themselves as Muslims. ${ }^{234}$ This is what Nirad Chaudhuri described, with regard to India, as "the State is secular . . . but the people are not." 235

Indeed, India presents an interesting example. Notably, India "is ruled by a Hindu majority [and] the Hindu concept of religion as a social identification is accepted virtually by all." ${ }^{236}$ How does that correspond with the principle of secularism? It is useful to revisit the

229. Garlicki, supra note 199, at 468. This traditional relationship between state and religion is of course not unique to Islam. As Garlicki notes there:

[h] istorically speaking, almost all countries formerly had a state church, and the political elite were more interested in establishing and maintaining religious peace than ensuring religious equality. In countries where historical development focused on evolution rather than revolution, there may still be found a very close linkage between a dominant religion and the state, namely Scandinavian countries and the Anglican Church in England. However, in a majority of Continental countries, the official relationship between church and state eventually broke down.

Id.

230. JefFrey T. Kenney, Islam in the Modern World 448 (Jeffrey T. Kenney \& Ebrahim Moosa eds., 2014).

231. Russell Powell, Does Shari'a Play a Role in Turkey?, 41 PePp. L. Rev. 1101, 1103-04 (2014).

232. Id. at 1111 .

233. Karagiannis, supra note 118 , at 1 ; see also Niyazi, supra note 124 , at 182; Stahnke \& Blitt, supra note 226, at 86.

234. Leininger, supra note 148 , at 821.

235. JACOBSOHN, supra note 59, at 36 .

236. Id. at 31 (quoting J. Duncan M. Derrett). 
case of R. C. Poudyal v. Union of India, in which it was held that the principle of secularism is a basic feature of the constitution. ${ }^{237}$ The Supreme Court faced a challenge to the reservation of seats in the legislative assembly of the Himalayan state of Sikkim for the sangha, the community of monastics. It was argued before the Court that this reservation violates the secular character of the Indian constitution that forms part of the basic structure. The Supreme Court ruled that:

[A] separate electorate for a religious denomination would be obnoxious to the fundamental principles of our secular Constitution. If a provision is made in purely on the basis of religious considerations for election of a member of that religious group on the basis of a separate electorate, that would, indeed, be wholly unconstitutional. But in the case of the Sangha, it is not merely a religious institution ... the Sangha had played an important role in the political and social life of the Sikkimese people. In view of this historical association, the provisions in the matter of reservation of a seat for the Sangha recognises the social and political role for the institution more than its purely religious identity. ${ }^{238}$

Here, the official secularism of the Indian state was confronted with the reality that is often shaped by religious idioms and institutions. This leads Martijn van Beek to propose that "the justification offered by the Supreme Court reflects not so much a doubting of the importance of validity of official secularism, but the belief that for the Himalayan Buddhist population, religion and monastic institutions are of overriding significance for local culture, society and identity." 239

It is this clash between the legal formal entrenchment of secularism with the often-religious reality that is fascinating and carries implication for the changing nature of the principle of secularism. Ignoring the reality of a predominantly religious country by forcing a strict separation of politics and religion is simply untenable. ${ }^{240}$ Why is it and why does it matter?

237. R. C. Poudyal v. Union of India, (1994) Supp. 1 SCC 324, 51.

238. Martijn van Beek, Enlightened Democracy: Normative Secularism and Spiritual Authority on the Margins of Indian Politics, in VARIETIES OF SECULARISM in Asia: ANThropological Explorations of Religion, Politics and the SPIRITUAL 75, 81-82 (Nils Ole Bubandt \& Martijn van Beek eds., 2012) (quoting Venkatachaliah, J.).

239. Id.

240. See Jürgen Habermas, Religion in the Public Sphere, 14 EuR. J. PHIL. 1, 9 (2006). And, as Habermas suggested, this would eventually turn into a mental burden on those citizens who follow a faith. $I d$. 
Baron De Montesquieu was one of the first political philosophers to develop the idea of an autonomous juridical order, which is composed of secular laws that are human responses to external objective problems and are diverse in light of society's changing circumstances. And already in 1748, in his famous $D e$ l'esprit des lois, Montesquieu famously claimed that laws:

[S]hould be in relation to the climate of each country, to the quality of its soil, to its situation and extent, to the principal occupation of the natives ... they should have relation to the degree of liberty which the constitution will bear; to the religion of the inhabitants, to their inclinations, riches, numbers, commerce, manners, and customs. ${ }^{241}$

Therefore, according to Montesquieu, each community should design its laws or legal system according to its particular spirit: historical, sociological, political, and economic conditions will shape particular legal systems. ${ }^{242}$ Montesquieu notes that attempting to alter the habits and customs of a people through laws would be tyrannical. ${ }^{243}$ Carl Joachim Friedrich notes that "[t]his is an injunction which it would have been well for quite a few of our contemporary legislators to remember." ${ }^{244}$

Montesquieu's approach is very much modern and realistic. It makes a connection between laws that ought to apply in a given community and the community's spirit. In that respect, it reminds me of the Volksgeist theory, coined by Friedrich Carl von Savigny, the father of the German historical school. According to Savigny, there exists "an organic connection between law and the nature and character of a people." ${ }^{245}$ The nature of particular legal systems reflects the spirit of the people who evolved them. For Savigny, law is not the result of an arbitrary legislator's act; it develops as a response to objective powers to be found in the people's national

241. See Charles-Louis De Baron De Montesquieu, The Spirit of the LAWS 6 (Thomas Nugent trans., 1752) (1748).

242. See Carl Joachim Friedrich, The Philosophy of Law in Historical PerspeCtive 105 (2d ed. 1963).

243. MonTESQUiEU, supra note 241, at 298.

We have said that the laws were the particular and precise institutions of a legislator, and manners and customs the institutions of a nation in general. Hence it follows that when these manners and customs are to be changed, it ought not to be done by laws; this would have too much the air of tyranny: it would be better to change them by introducing other manners and other customs.

Id.

244. FRIEDRICH, supra note 242, at 108.

245. See id. at 139. 
spirit and culture. In this respect, law reflects the national spirit, the Volksgeist. This view naturally grants utter importance to custom to which legislation must confirm. ${ }^{246}$

Is it therefore not dangerous to attempt to freeze indefinitely a norm that might last for only a while? What then, when the norm conflicts with the facts of reality? It appears to me that when there is a great discrepancy between the principles protected by unamendability and the values of the society-de l'esprit of the community to echo Montesquieu or the Volksgeist to borrow from Savigny - the constitution, with its unamendability, will be considered as a useless parchment barrier that may eventually be either ignored or completely replaced with a new one. As Benjamin Akzin sharply noted about eternity clauses:

One understands that we deal here with provisions which the respective Constitution-makers hold in particular esteem and to which they would like to give added protection. But if this esteem is shared by the rest of the politically-active groups, this by itself should ensure that the standard procedure for constitutional amendments would protect them sufficiently; if, on the other hand, the demand for change were to become so strong that it could overcome these standard procedure, it is hardly imaginable that its protagonists would renounce their objectives only because the Constitution says that the provision is inviolable. ${ }^{247}$

Indeed, no constitutional scheme can hinder the sway of real forces in public life for long or, as Silvia Sutue and I have demonstrated with regard to the "eternal" protection of "territorial integrity," ${ }^{48}$ can absolutely block extra-constitutional activity. Therefore, if society's demand for change of the secular nature of the state is so robust, constitutional rigidity with its so-called eternal protection might not succeed in blocking the sought change for long, even if it may hinder the change for a while.

What we now witness is challenges to constitutional secularism caused by the awakening of religious identity that develops into a major force of collective action. ${ }^{249}$ This occurs also in states in which

246. Frederick Charles Von Savigny, Of the Vocation of Our Age for LEGISLATION AND JURISPRUDENCE 24 (Abraham Hayward trans., 1831).

247. Benjamin Akzin, The Place of the Constitution in the Modern State, 2 ISR. L. REV. 1, 12-13 (1967).

248. Yaniv Roznai \& Silvia Suteu, The Eternal Territory? The Crimean Crisis and Ukraine's Territorial Integrity as an Unamendable Constitutional Principle, 16 GERMAN L.J. 542, 542 (2015).

249. András Sajó, Preliminaries to a Concept of Constitutional Secularism, in Constitutional Secularism in an Age of Religious Revival, supra note 70, at 54, 66 . 
secularism is granted an absolute entrenchment in the constitution. Tajikistan, as earlier mentioned, is a predominantly Muslimpopulated country where, on the one hand, following the communist approach the constitution declares the state to be secular and, on the other hand, there is an evident presence of religion in the lives of its citizens. ${ }^{250}$ Hakim Zainiddinov is probably correct in his observation that:

Being the religion of the absolute majority and an integral part of the social, economic, and political life of Tajikistan's people, Islam was artificially and forcefully separated from the state. Perseverance on the same policy might cause the formation of radical religious groups or serve as a powerful trigger in turning moderate Islamists to extremism. ${ }^{251}$

Similar tensions exist in Turkey. Gary Jacobsohn writes about the fraught relationship between the Turkish eternity provision that shields secularism and religious movement's demands:

Can we then know with certainty what is and is not irrevocable when speaking of Turkish constitutional identity? I would suggest that an affirmative response ought to be received skeptically. The reason for such uncertainty is not unique to the Turkish case . . instead it lies in the dynamic quality of identity and the dialogical process by which it is formed and develops. Turkey's secularism, for example, was not a simple product of the imagination, but was and remains embedded in a deep cultural matrix from which counter-pressures to the dominant ideology exert a continuing, if irregular, force . . . ${ }^{252}$

As Tyulkina pondered about the Turkish situation, "Turkey is a predominantly Muslim state, which makes it even harder for the majority of the population to accept the policy of complete detachment of religion from politics." ${ }^{253}$ The eternity protection of secularism, coupled with substantive judicial review of constitutional amendments and the banning of political parties, artificially removed religion from the public conversation. ${ }^{254}$ According to her, "[N]o state can succeed in building a true democracy if it imposes

250. See supra Subsection II.A.2.

251. Zainiddinov, supra note 98, at 476-77.

252. Gary Jeffrey Jacobsohn, If an Amendment Were Adopted Declaring the United States a Christian Nation, Would It Be Constitutional? Well . . Let's Look at Turkey, U. MD. CONST. L. 'SCHMOOZE' PAPERS (Feb. 2009), http://digitalcommons. law.umaryland.edu/cgi/viewcontent.cgi? article $=1103 \&$ context $=$ schmooze_papers [https://perma.cc/379Y-Q5YJ].

253. TYULKINA, supra note 81, at 176.

254. Id. at 180 . 
principles and views that people do not share and is wilfully deaf to what is happening in society." 255

Indeed, the abolishment of the headscarf ban in Turkey demonstrates that "it is not possible for democracy to indefinitely sustain policies of suppression and ignorance of the demands brought by a large proportion of the population. Rather, there is a need to accommodate them through dialogue, negotiation, and compromise." ${ }^{256}$ As Ahmet Kuru and Alfred Stepan summarize events in Turkey, "[T]hese changes indicate the democratization will eventually result in the liberation of the state practice of laïcite in Turkey. Historical path dependence matters, but it does not impose a deterministic and unchangeable understanding of laïcité."257 Put differently, when the designation of a principle as eternal conflicts with the spirit of society, the protected principle is destined to be negotiated, explicitly or implicitly. ${ }^{258}$ People's lives move, develop, and change. Law-regardless of any verbal designations to the contrary - is no exception and is subject to these changes. ${ }^{259}$

Writing on the eternal protection of secularism in the Malian Constitution, Lacabanne states that in contrast with the unchangeable past, ${ }^{260}$ nothing is unchangeable neither in law nor in fact. The constitutional protection of secularism or any other eternal principle for that matter will continue only as long as the populations recognize these principles and find it necessary to adhere to them. However, on the day when people will abandon these principles in favor of a new set of values, even these eternal principles will

255. Id. at 181 .

256. Id. at 183 .

257. Kuru \& Stepan, supra note 97, at 104.

258. Compare Kuru \& Stepan, supra note 97, at 104, with Sajó, supra note 33, at 2428 ("In pragmatic terms the actual Western choice of constitutionalism is a negotiated one. It may well be that we will reach a point where religions and churches will become much more powerful in these negotiations, and there will be a moment where the religious position will prevail in constitutional law. At that moment it will be the choice made by religion, and not people's choice, that will matter, even if that choice was endorsed by a majority consisting of fundamentalist believers. In the unlikely case where all people voluntarily choose religion you can't say that the policies will be, for this reason, sovereign choices of the people consisting of sovereign, autonomous individuals. The choices will be that of (to a great extent pre-existing, taken for granted, non-negotiated) religion.").

259. James A. Gardner, Legal Idealism and Constitutional Law, 10 VILL. L. REV. 1, 21 (1964).

260. While this is true as a matter of fact, it is inaccurate as a matter of norm, since the law can retroactively change past legal situations. See DANIEL E. Troy, RETROACTIVE LEGISLATION 6-8 (1998). 
change. Unamendability, he correctly writes, is not one of constraint but of will. Law must know how to evolve with time. ${ }^{261}$

In the next Part, I review the idea of eternal law in religious and natural law in order to later demonstrate the paradox of using eternity clauses in order to shield the principle of secularism.

\section{THE CIRCLE OF ETERNITY}

The final Part of this Article aims to point to a paradox underlying the constitutional eternity of secularism. It begins by expounding upon the centrality of the notion of eternity in religious laws, mainly in Judaism, Islam, and Christianity and in natural law thinking. It then briefly describes developments during the age of rationalization throughout the renaissance, reformation, and enlightenment, an age that emphasized human reason yet maintained a certain notion of eternity through the idea of natural rights. Finally, it points to a paradoxical notion in describing the constitutional principle of secularism as eternal, which is based on the everchangeable nature of secular law and rejection of transcendent absolute truths in the secular age. The description of certain constitutional principles as eternal closes the circle of eternity which begins with religions.

A. Lex Temporalis \& Lex Aeterna: Eternity in Religious Laws and Natural Laws

The idea of eternity is strongly linked to religions. Religions provide for eternal truths. Since God's will is immutable, religious laws-defined here as laws that are rooted in the Holy Scriptures from which they derive their authority ${ }^{262}$-are not the product of deliberations or compromise and are deemed unchangeable. ${ }^{263} \mathrm{In}$ these respects, they differ very much from secular laws. Notwithstanding the fact that even religious laws include various flexible mechanisms for certain adaptations, ${ }^{264}$ the conventional

261. Lacabanne, supra note 147, at 15-16.

262. See generally Mulford Q. Sibley, Religion and Law: Some Thoughts on Their Intersections, 2 J.L. \& RELIGION 41 (1984) (providing an overview of the historical relations of law and religion).

263. Lorenzo Zucca, A Secular Europe: Law and Religion in the EUROPEAN CONSTITUTIONAL LANDSCAPE 178-79 (2013).

264. On Religion's competing interests in providing eternal truths while showing sensitivity to the problems of the here and now, see ZE'EV FALK, RELIGIOUS 
understanding is that religious laws are inherently different from secular laws, being eternal and immutable. ${ }^{265}$

In Judaism, for example, Chapter 13 of The Book of Deuteronomy (the fifth book of the Torah, Mishneh Torah) opens with the following canonical phrase: "What thing soever I command you, observe to do it: thou shalt not add thereto, nor diminish from it." ${ }^{266}$ Joseph Weiler notes that this phrase should be read together with the oft-repeated assertion in Deuteronomy that "this Law is a Chukat Olam, a law forever, for 'a thousand generations."'267 The reader, he observes, is thus instructed that a divine authority sets out the material content of the long and immutable list of Mosaic commandments ("Law of Moses"-Torat Moshe). ${ }^{268}$

In his article, "Midrash: Amendment through the Molding of Meaning," Noam Zohar writes that in light of the revealed God's authority, it would appear that "God has spoken: All that remains is to obey. . . . If the Law is invested with God's authority, how can it ever be amended?"269 "It would appear that the only avenue for amendment must be some new revelation, wherein God Himself

Law Between Eternity and Change: On the Dynamism of Jewish Law in Jewish Thought and on Jewish, Christian and Muslim AtTitudes Towards Legal Change (Jerusalem 1986) (Heb.); Jacob Katz, Divine Law in Human Hands - CASE Studies in Halakhic FleXibility (1998).

265. Ya'akov Meron, Religious Law Between Eternity and Change, on the Dynamism of Jewish Law in Jewish Thought and on Jewish, Christian and Moslem Attitudes Towards Legal Change by Ze'ev W. Falk, 65 Studia Islamica 180, 180 (1987) (book review); see also KATZ, supra note 264, at 7-8 ("Halakah as religious or rather, revealed law, is according to its own self-understanding unchangeable. . . . For some people, the observable changes in halakhah during the course of history will support the negation of its eternal validity. For others, its adaptability to changing conditions will guarantee its continued preservation."); Noam J. Zohar, Midrash: Amendment Through the Molding of Meaning, in RESPONDING TO ImPERfeCtion: The TheORY AND PRACTICE of CONSTitutional AMENDMENT 307 (Sanford Levinson ed., 1995) (demonstrating how "just as in the modern state specific laws can be changed or repealed without affecting the underlying constitution, so (arguably) can some details of Jewish law be altered without impinging upon the divine "constitution[,]"' and arguing that notwithstanding some conceptual and operational differences, "[H]alakhic Midrash is functionally equivalent to constitutional amendment.").

266. J. H. H. Weiler, The Judeo-Christian Tradition and the Dialectic of Difference: An Examination of Four Dimensions of Jewish Prayer, 1 J.L. PHIL. \& Culture 3, 8-10 (2010).

267. Id.

268. Id. at 8-10.

269. Zohar, supra note 265, at 308. 
would announce laws supplanting His previous decrees."270 However, Zohar notes that the tradition of Jewish law rejects divine intervention following the initial revelation. ${ }^{271}$ This is famously manifested in the Talmudic story of "Oven of Achnai." 272 Thus, the most amazing point with the entrenchment in Deuteronomy, Chapter 13 , is not only the fact that the community is forever bound by God's eternal law, but that God also binds himself through this absolute entrenchment. $^{273}$

It would thus appear that the notion of immutability precludes any amendments to the scriptural law, and allows only a limited scope for interpretation, which conforms and respects the initially received law. ${ }^{274}$ As Zohar highlights:

[T] he core revelation functions like a constitution, setting the parameters for rabbinic legislation. Legal change is easily accounted for with respect to most of the halakhic corpus. The authority of the core "constitution" is,

270. Id.

271. Id.

272. Superficially, the story deals with the question whether a certain type of oven is susceptible to ritual impurity. At a deeper level, the issue is whether the authority to decide Jewish Law resides on earth or "in the heavens." According to the story, Rabbi Eliezer brought forward various arguments to support his position, but the rest of the sages disagreed with him. He then told them: "If the Halakha agrees with me, let this carob tree prove it!" The carob tree was immediately torn a hundred cubits out of its place - others affirm, four hundred cubits. "No proof can be brought from a carob tree," they retorted. Then he said, "If the Halakha agrees with me let the stream of water prove it." And so the stream of water flowed backwards. "No proof can be brought from a stream of water," they replied. He then insisted, "If the Halacha agrees with me, let the walls of the schoolhouse prove it," at which point the walls tended to fall. But Rabbi Joshua rebuked them saying: "When scholars are engaged in halachic dispute, what right have you to interfere?" Hence they did not fall in honor of Rabbi Joshua, nor did they resume the upright position in honor of Rabbi Eliezer, and they are still standing thus tending. Then he said to them, "If the Halakha agrees with me, let it be proved by Heaven." Whereupon a Heavenly voice cried out: "Why do you dispute with Rabbi Eliezer, seeing that in all matters the Halakha agrees with him." But Rabbi Joshua arose and exclaimed: "it [the Torah] is not in Heaven" Deuteronomy 30:12. What did he mean by this? Rabbi Yermiah said: "That the Torah had already been given at Mt. Sinai; therefore we pay no attention to a Heavenly voice, because you have long since written in the Torah at Mount Sinai, 'One must follow the majority." Exodus 23:2. See Katz, supra note 264, at 261-62; Howard Schwartz, TREe OF Souls: The MYthoLOGY OF JudAism 67 (2004).

273. Weiler, supra note 266, at 11.

274. Zohar, supra note 265 , at 309. The Maimonides, Zohar notes, distinguished between a core revelation that can never be changed and the remainder of the law-traced to rabbinic implementation-and subject to constant reevaluation. $I d$. at 315 . 
however, held to be absolute: Any change or amendment of the revealed Torah is expressly ruled out - even if authored by God Himself. ${ }^{275}$

In rabbinic Judaism, he writes, "[T] override the absolute commitment to the initial revelation." 276 Although the meaning of text is ultimately flexible, it is "eternally fixed." 277

Menachem Elon, a leading authority on Jewish law and former justice at the Israeli Supreme Court, summarizes:

What is the basic norm of Jewish law? It is the fundamental norm that everything set forth in the Torah, i.e., the Written Law, is binding on the Jewish legal system. The basic norm of Jewish law is thus more than the source of a chain of authority. It is also intertwined with the substantive content of the Written Law as the permanent constitution of the Jewish legal system - a constitution not subject to modification, either by addition or subtraction. This norm is the source of authority and the starting point for the entire Jewish legal system in all its periods, changes, and developments; it authorizes the legal sources of Jewish law to serve as effective means for continued creativity and development. ${ }^{278}$

It is God's command itself, as embodied in the Torah, which was given to Moses at Sinai. Since the "Torah is from Heaven[,]" (Torah min ha-shamayim) it carries an immutable eternal character.

Similar to Judaism, within Islamic Law (Sharia), the transcendent law is eternal and unchangeable. ${ }^{279}$ The Quran, one of the formal sources of Islamic Law, ${ }^{280}$ is the most sacred source of law as it is believed to contain God's direct revelations to the Prophet Muhammad. "These were embodied in permanent written form in the Quran shortly after the death of Muhammad in 632 CE." ${ }^{281}$ Ann Lambton writes that in light of its divine character,

275. Id. at 316.

276. Id. at 318 .

277. Id.

278. Menachem Elon, 1 Jewish Law: History, Sources, Principles 232 (Bernard Auerbach \& Melvin J. Sykes trans., 1994) (emphasis added). Interestingly, in a footnote, Elon compares this integration of the basic norm with substantive content to modern constitutions that protect basic constitutions from amendments. He provides there the examples of France, Italy, Brazil, and Norway. See id. at n.10.

279. ASHK P. DAHLÉn, ISLAmic LAW, Epistemology AND MOdernity: LEGAL PHILOSOPHY IN CONTEMPORARY IRAN 50 (2003).

280. The other sources are the sunna (verbally transmitted record prophet Muhammad's teachings), qiyās (analogical reasoning), and ijma $\bar{a}^{c}$ (scholarly consensus).

281. JonAthan ERCANBrack, The TRANSFORMation OF IsLAmic LAW IN Global FinANCIAL MaRKETS 23 (2015). 
Sharia is pre-existing and eternal. ${ }^{282}$ Likewise, Noel Coulson qualifies Sharia as "a rigid and immutable system, embodying norms of an absolute and eternal validity, which are not susceptible to modification by any legislative authority." ${ }^{283}$ And Ron Geaves refers to the Quran as a text "deemed to be the eternal and complete revelation of God to all humankind." ${ }^{284}$ Again, in light of its divine source (as it is legislated by God), Sharia is above human law; it is an immutable and rigid system of law. ${ }^{285}$ In divine ideology, God is "the first and eternal legislator." 286

This idea of eternal law is a central aspect of Christianity, as most dominantly manifested in the development of legal philosophy at the Christian Middle Ages. Perhaps most prominent is St. Augustine, who is "in truth the fulfilment and perfection of Christian antiquity, its last and its greatest thinker, its spiritual practitioner and tribune." ${ }^{287}$ Augustine is "the father of medieval Catholicism." ${ }^{288}$ In his work, the Church — as a higher community—stands above the polis, above the civitas. The civitas Dei, the city of God, exists in heaven and not in earth, yet it is represented earthly by the community of faithful, which is visibly represented by the church. The church is imbedded in the civitas terrena, the secular community of mankind, which is organized into different political bodies. There is a division between the two spheres; the civitas Dei and especially the church, its representative on earth, is responsible for realization of the higher values. The secular political community, the civitas terrena and its sectors, in contrast, remain responsible for the ordering and upholding of peace. The state is subjected to the measures of justice represented by the Church, which rests upon

282. Ann K. S. Lambton, State and Government in Medieval Islam: An Introduction to the Study of Islamic Political Theory: The Jurists xiv (1981).

283. N. J. COUlson, A History Of Islamic LAW 5 (1964); see also Rudolph Peters \& Peri Bearman, Introduction: The Nature of the Sharia, in THE Ashgate Research Companion to Islamic Law 3 (Rudolph Peters \& Peri Bearman eds., 2014).

284. RON GEAVES, ISLAM TODAy 43-44 (2010).

285. See, e.g., ERCANBRACK, supra note 281, at 31 ("[T] God remains an absolute obligation for the individual.").

286. See DAHLÉN, supra note 279, at 153 (citing Mahdī Bāzargān).

287. See Friedrich, supra note 242, at 35 (citing ERnSt Troeltsch, Augustin, DiE CHRISTLICHE ANTIKE UND DAS MitTElalter (1915)).

288. F. J. E. Raby, A History of Christian-Latin Poetry: From the Beginnings to the Close of the Middle Ages 20 (1927). See also Charles Howard McIlwain, The Growth of Political Thought in the West: From the GReEKS to THE END OF THE Middle Ages 154-60 (1932). 
divine revelation; and therefore is in a higher position to judge whether a specific rule or government is acting justly or not. Carl Friedrich notes that this split that created an interdependence of state and church led centuries later to the separation of church and state. ${ }^{289}$

This concept of justice as limits to law is a recurring idea in Augustine, who writes that "Mihi lex esse von videtur, quae justa non fuerit ('it seems to me that that which would not be just is not law')." ${ }^{290}$ Law, not only as an individual statute - but as a wholemust be understood as an emanation of justice. ${ }^{291}$ However, there is still a clear distinction between law and morals. Positive or ordinary law (lex temporalis) punishes for the violation of a particular rule ordering the peace. It is therefore limited since it only prevents evils but does not make men good. And most importantly, positive law relates to the unimportant realm of this world. The truly important realm is that of eternal life that is subject to the eternal law (lex aeterna). But there is an important link: The eternal law of God limits all positive law that the latter may not transgress without losing its quality of law. ${ }^{292}$

St. Augustine's writings had a dominant influence on Thomas Aquinas, the most influential philosopher of the Middle Ages. In his Summa Theologiae, Aquinas distinguishes between different kinds of law. The first is eternal law, which is the reason of divine wisdom that governs the whole community of the universe. "[S]ince the divine reason's conception of things is not subject to time but is eternal," Aquinas writes, "this kind of law must be called the eternal law." ${ }^{293}$ Then, there is natural law, which is "participation in the eternal law by rational creatures;" ${ }^{294}$ is that part of the divine law that is revealed to man through reason. It is the participation in eternal law typical for rational creatures. ${ }^{295}$ Natural law, apart from its basic

289. FRIEDRICH, supra note 242, at 35-39.

290. Id. at 39 (citing Augustine, De Civitas Dei xix. 21).

291. Id. In his translation of The Two Cities, Alan Ryan, translates this as "where, therefore, there is no true justice there can be no right." See AlAn RyAn, ON Augustine-The Two Cities 196 (2016).

292. See FRIEDRICH, supra note 242, at 40.

293. St. Thomas Aquinas, Summa Theologiae I-II [The Summa of Theology, 1269-1270], in St. Thomas Aquinas on Politics and Ethics 30, 46 (Paul E. Sugmund trans. \& ed., 1988).

294. Id.

295. Martin Rhonheimer, Natural Law as a "Work of Reason": Understanding the Metaphysics of Participated Theonomy, 55 AM. J. JuRIS. 41, 51 (2010). Rhonheimer mentions that the notion that "moral life is based upon "the 
first principles, is changeable. ${ }^{296}$ Thus there is an "immutable ontological foundation" to moral principles. ${ }^{297}$ Natural law, as a general norm above positive law, can bring Christian justice. ${ }^{298}$ Finally, there are human laws, which are those particular dispositions arrived at by human reason. ${ }^{299}$ What if a human law deviates from the right reason? Then, according to Aquinas, it is:

an unjust law, and thus does not have the character of a law but rather that of an act of violence. However, even an unjust law to the extent that it maintains the appearance of law because of the authority of the one who makes it is derived in this respect from the eternal law. ${ }^{300}$

Human positive law implements the divine eternal law and natural law by dealing with the specific problems of a concrete community. ${ }^{301}$ Importantly, for Aquinas, human law-as a dictate of reason that directs human action - can be changed. His words are worth citing in full:

Reason may cause laws to be changed because it seems to be the nature of human reason to progress by stages from the less perfect to the more perfect. Thus we see that in the speculative science the teachings of the early philosophers were inadequate, and later their successors improved them. The same thing is true in practical affairs. Those who first tried to discover something useful for the human community were not able to take account of everything by themselves and established institutions that were inadequate in many respects. These were then modified by their successors who set up institutions that proved to be less deficient from the point of view of the public interest.

Those whose actions are regulated by the law may cause a law to be changed if the circumstances have changed that make different laws appropriate for different circumstances. ${ }^{302}$

Accordingly, human laws change due to the progress of the nature of human reason and the changing circumstances. For Aquinas, secular authority is subject to spiritual authority; and it is the church - the guardian of spirituality - that ought to judge the

impression in us of the knowledge of the eternal law" is affirmed also in Aquinas' De libero arbitrio. Id. at 45.

296. AQUINAS, supra note 293, at 51-52.

297. Luis CORTEST, The Disfigured Face: Traditional Natural LaW AND ITS ENCOUNTER WITH MODERNITY 15 (2008).

298. FRIEDRICH, supra note 242, at 43.

299. Id. at 44 .

300. AQUINAS, supra note 293, at 48.

301. FRIEDRICH, supra note 242, at 44.

302. AQUINAS, supra note 293, at 56. 
actions of the prince: "Kings must be subject to priests." ${ }^{303}$ If the princes fail to act in accordance with Christian views, their commands cease to be laws and must be disobeyed-"Man is bound to obey secular rules to the extent that the order of justice requires ... [but if rulers] command things to be done which are unjust, their subjects are not obliged to obey them; except, perhaps, in certain special cases, when it is a matter of avoiding scandal or some particular danger." 304

The idea of an eternal aspect of law is recurring in Christian theology. Pope Leo XIII, for example, wrote that "the law of nature is the same thing as the eternal law, implanted in rational creatures, and inclining them to their right action and end; and can be nothing else but the eternal reason of God." ${ }^{305}$ For Pope Leo, true liberty belongs to those who obey God. ${ }^{306}$ This idea of immutability also appeared in the writings of Pope John: "universal, absolute and immutable [order] in its principles-finds its sources in the true, personal and transcendent God." ${ }^{307}$ According to the early Church, "Temporal institutions were sacred only so far as they conformed to eternal standards." 308

The idea of a natural law as representing an immutable idea of justice goes back to the Greeks. ${ }^{309}$ After identifying laws of nature that control the cycles of daytime and seasons, the Greeks explored whether similar natural laws govern the human conduct. Through their reason, humans have an inherent ability to distinguish between right and wrong. Nature is the order of reason that is expressed in the form of fundamental laws, and these laws are superior to the customs of particular societies. ${ }^{310}$ The Greeks have distinguished between local positive law, which is changeable, and what is just by nature, which is "unwritten, universal, eternal, and immutable." ${ }^{311}$ The identity of natural law (jus natural) with reason and human nature was a key assumption of Stoicism, which considered morality's

303. FRIEDRICH, supra note 242, at 47.

304. Id.

305. CORTEST, supra note 297 , at 71.

306. Id. at 72 ("[T] he eternal law of God is the sole standard and rule of human liberty ....").

307. Id. at 87 .

308. Gardner, supra note 259, at 8-9.

309. Hannah ARendt, The Human Condition 173-74 (1958); Martin Loughlin, Sword \& SCAles: An Examination of the Relationship BetweEN LAW \& POLITICS 10 (2000).

310. LoughLin, supra note 309, at 10.

311. Gardner, supra note 259, at 3. 
positive content in harmony with nature, as adapted to human nature. Nature, human nature, and reason were all one in a way the men participated with the Gods through their rational capacity. ${ }^{312}$

This idea was manifested by Cicero who introduced the Stoicism to Rome. For Cicero, there is a universal natural law, which is derived from the divine governance and the rational nature of humans. This is the universal constitution; it is similar everywhere and binding, without a change, on all humans. No conflicting law can be considered as law. ${ }^{313}$ As Cicero writes in De Legibus (On the Laws): "There is indeed a true law (lex), right reason, agreeing with nature and diffused among all, unchanging, everlasting . .." 314 From Cicero the idea of natural law arrived to Roman jurists, and perhaps even more importantly, to the fathers of the church, and Cicero works were cited countlessly throughout the Middle Ages. Therefore the juridical meaning of "natural right" and "natural law" (ius natural), introduced into medieval moral philosophy and theology, had a clear moral connotation and was about natural reason. ${ }^{315}$

To conclude, immutable principles are strongly connected to the religious context of eternal law. ${ }^{316}$ Like religious laws, natural laws are immutable in some sense. Natural law, as right reason, was considered permanent. The classical distinction between divine law, natural law, and human, or positive, law is the unchangeable and eternal nature of the former and the changeable and temporal nature of the latter.

\section{B. Secularism and the Age of Rationalization}

During the Middle Ages, sovereignty was a mark of superiority signified through some divine source. With the emergence of the modern idea of the State, however, political power became differentiated from heavenly authority, and sovereignty was

312. Id. at 4-5. Stoic natural law, however, "[W]as conceived as being identical with the eternal law of the cosmos." Rhonheimer, supra note 295, at 45.

313. George H. Sabine, A History of Political Theory 178-79 (3d ed. 1963) (citing CiCERO, THE REPUBLIC, II, 22) (Heb.).

314. H. Verlan Andersen, The Moral Basis of a Free Society 5 (1995) (citing De LeGIBUS (ON THE LAWS) II, 4, 10).

315. Rhonheimer, supra note 295 , at 42.

316. Some scholars, such as Michael Crowe, the idea of an "immutable" truth is illusionary since morel precepts are time-conditioned and culture-bound. See Michael Bertram Crowe, The Changing Profile of the Natural Law 288 (1977). 
transformed into an earthly symbol of authority. ${ }^{317}$ How, then, can the political order be justified? In the sixteenth century, Bodin had asserted that sovereignty is the highest power of command that constitutes "the absolute and perpetual power of the commonwealth." ${ }^{318}$ However, for Bodin it was still God at the apex of the system. ${ }^{319}$ It is thanks to the contribution of the seventeenthcentury Dutch jurist Hugo Grotius that advanced secular political theory. In his De Jure Belli ac Pacis, Grotius contends that laws would maintain their objective validity "even if we should concede that which cannot be conceded without the utmost wickedness, that there is no God." ${ }^{20}$ Grotius believed that given the human nature, natural law precepts followed as a matter of logic; a disposition that "has been implanted in us partly by reason, partly by unbroken tradition." "321 Grotius claimed that law embodies principles of just conduct that are revealed through the exercise of powers of reason and tradition. ${ }^{322}$ The idea of law as a set of principles of just conduct continues to exert a powerful influence over modern thinking. Grotius identified the rationalistic conception law as reason, or of right. Richard Tuck, for example, notes that De Jure Belli ac Pacis "is in fact the first reconstruction of an actual legal system in terms of rights rather than laws," and therefore "the true ancestor of all the modern codes which have rights of various kinds at their centre." ${ }^{323}$

The idea of secular political order was central to Thomas Hobbes. Applying natural sciences to the study of social and political phenomenon, Hobbes conceived human action in terms of physical

317. Brian Tierney, The Crisis of Church ANd State, 1050-3300 at 18889 (1964). On the secularization of government within mediaeval origins, see Martin Loughlin, Foundations of Public Law 37-46 (2010).

318. JeAn Bodin, Les Six Livres de la Republique 87 (1576); see Bodin, ON SovereIgnTy 1 (Julian H. Franklin ed., 1992). On Bodin's method, see LOUGHLIN, supra note 317 , at 56-73.

319. JEAN Bodin, ON Sovereignty 10 (Julian H. Franklin ed., 1992) (explaining that "if we say that to have absolute power is not to be subject to any law at all, no prince of this world will be sovereign, since every earthly prince is subject to the laws of God and of nature and to various human laws that are common to all peoples").

320. Hugo Grotius, Prolegomena to the Law of War and Peace $§ 11$ [1625] (Edward Dumbald ed., Liberal Arts Press, 1957).

321. Id.

322. LOUGHLIN, supra note 309, at 10-11.

323. Richard Tuck, Natural Rights and Theories: Their Origin AND DEVELOPMENT 66 (1976). 
matter in motion. ${ }^{324}$ In Leviathan, he describes the state as an artificial construct; using mechanical metaphors to explain the nature of the state like those "engines that move themselves by springs and wheels as doth a watch," ${ }^{25}$ a metaphor that implies that the sovereign is a human not a God-given construct. ${ }^{326}$

The idea of natural law as a set of objective moral principles that should guide our actions is central to John Locke's philosophy. Locke writes that:

Thus the law of nature stands as an eternal rule to all men, legislators as well as others. The rules that they make for other men's actions, must . . . be conformable to the law of nature, i.e. to the will of God, of which that is a declaration, and the fundamental law of nature being the preservation of mankind, no human sanction can be good, or valid against it. ${ }^{327}$

Locke believed in natural law as that which expresses what we ought to do and which therefore guides our actions. And for Locke, "[T]he end of law is not to abolish or restrain, but to preserve and enlarge freedom." 328 The purpose of political society is to maintain and extend natural freedom. Individuals, he claimed, possess certain inalienable natural rights. This idea of natural rights had an enormous influence on late eighteenth century developments, as evident by the Declaration of Right of Virginia, ${ }^{329}$ the American Declaration of Independence, ${ }^{330}$ and the French Declaration of the

324. See generally Thomas Hobbes, Elements of Philosophy (1656); see David Johnson, The Rhetoric of Leviathan: Thomas Hobbes and the Politics of Cultural Transformation (1986); Quentin Skinner, Reason and Rhetoric IN THE Philosophy of HobBes 327-75 (1996) (arguing that in Leviathan, Hobbes attempts to bring together the methods of science with the rhetoric techniques of Renaissance humanism).

325. Thomas Hobbes, Leviathan 9 (Richard Tuck ed., Cambridge Univ. Press 1996) (1651).

326. LOUGHLin, supra note 309 , at 33.

327. John Locke, Two Treatises of Government II $\S 135$ (C.B. Macpherson ed., 1980) (1690).

328. Id. at $\S 57$.

329. DeClaration of Rights art. 1 (Va. 1776) ("[A]ll men are by nature equally free and independent, and have certain inherent rights, of which, when they enter into a state of society, they cannot by any compact deprive or divest their posterity.").

330. The Declaration of IndePendence para. 2 (U.S. 1776) ("We hold these truths to be self-evident, that all men are created equal, that they are endowed by their Creator with certain unalienable Rights, that among these are Life, Liberty and the pursuit of Happiness. - That to secure these rights, Governments are instituted among Men, deriving their just powers from the consent of the governed ...."). 
Rights of Man and Citizen, ${ }^{331}$ all of which recognize rights as existing prior to the sovereign power and the constitutional order.

Of course, the claim that all humans have natural rights needs some foundation. ${ }^{332}$ One basis would be, of course, an appeal to a divine religious creator. In a secular age, another basis would be to appeal to an unchanging human nature, an unlikely option, as Loughlin mentions, given the vagaries of human history. ${ }^{333}$ Another alternative is to discover the structure of ethical order embedded within human reason itself. ${ }^{334}$ In his Rights of Man, Thomas Paine explains that these rights are natural because they "appertain to man in right of his existence." ${ }^{335}$ Since government is now being reconstructed in accordance with the principle of natural rights, Paine calls the present age "the Age of reason." 336

Modern secularism was therefore developed through the increasing confidence in human capabilities, reason, and progress, which have emerged during the Italian Renaissance, the German Reformation's distrust toward religion, and the French Enlightenment. ${ }^{337}$ Indeed, a central feature of the Renaissance (1350$1600)^{338}$ was the focus on the individual as a free, dignified, and rational human being. It is also when the secular approach to politics

331. The Declaration of the Rights of Man and of the Citizen art. 1 (1789) (Fr.) ("Men are born and [always continue,] free and equal in [respect of their] rights"); see also id. at art. 2 ("The aim of [all] political association is the preservation of the natural and imprescriptible rights of man. These rights are liberty, property, security, and resistance to oppression.").

332. Some, of course, have claimed the idea of 'natural' rights is fictional. See Alasdair Macintyre, After Virtue: A Study in Moral Theory 69 (Univ. Notre Dame Press 2d ed. 1984) (1981) ("[T]here are no such rights, and belief in them is one with belief in witches and in unicorns."); Gregory J. Walters, Macintyre or Gewirth? Virtue, Rights, and The Problem of Moral Indeterminacy, in Philosophical Theory and the Universal Declaration of Human Rights 183, 187 (William Sweet ed., 2003).

333. LOUGHLIN, supra note 309, at 201.

334. Id. (referring to Emmanuel Kant, Perpetual Peace: A Philosophical Sketch, in Kant Political Writings (Hans Reiss ed., Cambridge Univ. Press $2 \mathrm{~d}$ ed. 1991)).

335. Thomas Paine, Rights of Man, in Rights of Man Common Sense And Other Political Writings 119 (Mark Philip ed., Oxford Univ. Press 1995).

336. Id. at 321.

337. MARBANIANG, supra note 59, at 11-12; see also DOMENIC Marbaniang, The Story and Meaning OF SeCularism (2012).

338. Renaissance was the rebirth of classical humanism, spreading from Italy to Germany, France, England, and Spain in the late fifteenth and sixteenth centuries. See Marvin Perry, Western Civilization, A Brief History 186-213 (10th ed. 2012). 
has been further developed by Niccolo Machiavelli. ${ }^{339}$ German Reformation (1517-1648) represents the era of privatization of religion and freedom from Papacy. ${ }^{340}$ And, a central feature of the Age of Enlightenment (1715-1789) was the confidence in human reason. It is reason, rather than religion, that would guide us between truth and falsity. As Jean Jacques Rousseau emphasized in his Social Contract, when referring to Grotius' writings, "These principles are not . . . based on the authority of poets, but derived from the nature of reality and based on reason." ${ }^{341}$ Enlightenment thinkers believed that it is reason instead of religion that should be the reference point for knowledge. And of course the scientific revolution with Galileo, ${ }^{342}$ Newton, ${ }^{343}$ and Darwin's Origin of Species, ${ }^{344}$ left no place for God.

Immanuel Kant described the Enlightenment as "our release from our self-imposed tutelage." 345 Therefore, Enlightenment is also called "the Age of Reason" by reflecting the supremacy of reason over faith or revelation. ${ }^{346}$ But there is still an element of eternity; Natural rights, as developed in the eighteenth century, were considered natural, inherent, universal, and eternal. ${ }^{347}$

339. See his classical work THE PRINCE (Quentin Skinner \& Russell Price eds., Cambridge Univ. Press 1988), which represents a shift from a political theory based on ethics and metaphysics to realism.

340. See generally TOM Scott, The Early Reformation in Germany: BetweEn SECUlar IMPACt AND RADiCAL Vision (2013).

341. Jean-Jacques Rousseau, The Social Contract 20 (G.D.H. Cole trans., Cosimo 2008) (1762).

342. See, e.g., Rivka Feldhay, Galileo And the Church (1995).

343. Newton demonstrated that the physical universe was governed by certain universal and eternal principles. See IsaAc Newton, A Treatise of the SYSTEM OF THE WORLD 5 (1728).

344. See generally Charles Darwin, On the Origin of Species (David Knight ed., Routledge 2003) (1859).

345. Alister E. McGrath, The Making of Modern German Christology 14 (Inter-Varsity Press $2 d$ ed. 1994).

346. See id. at 15.

347. Gardner, supra note 259, at 15-16. Martin Loughlin writes that:

The idea of a natural law operating on a higher level than the conventions of politics seems intelligible only when linked to the existence of a creator: having designed an ordered universe, God placed humans in the unique position of being able to reflect on the rational order of the cosmos. Modern natural rights theories have tried to avoid this dependence of law on theology by devising a conception of law as a construction of reason.

See Loughlin, supra note 309, at 10. 
In the next Section, I wish to present the challenge, how the enlightenment rejection of imposition corresponds with constitutional eternity or unamendability.

\section{The Paradox of Modern Constitutional Eternity}

In his book A Secular Europe, Lorenzo Zucca distinguishes between religious, natural, and secular law. The three belong to discrete domains of analysis: religious laws belong to the sacred, which cannot be proved; natural laws belong to the natural, which can be proved; and secular laws belong to the juridical. ${ }^{348}$ In opposition to religious laws, secular laws do not rely on divine authority. And in contrast with natural law, they are secular since they are created by humans. Most importantly, secular laws, in contrast with religious laws, are produced by deliberations and compromises in order to obtain a certain degree of social harmony and order, and are contingent and changeable. Their purpose is to create a framework within which all individuals living in a territory can organize their life in an orderly and peaceful manner. Secular laws thus have the goal of stabilizing competing forces in society in order to achieve and maintain a well-ordered society. But in contrast with religious laws, they can aim at the goal of a well-ordered society (which in itself may take a variety of forms), while preserving an infinite number of paths that can lead there. ${ }^{349}$

Secular laws, in contrast with religious laws, offer a space for disagreement deliberations, as they do not rely on a divine command. This is surely correct with regard to positivism such as Hans Kelzen's pure theory of law, for whom law excludes any influence of religious and natural laws. ${ }^{350}$ "In the age of secularism," David Dyzenhaus notes, "the only candidate we have for rightness is the beliefs we have in the light of our deliberations about our

348. ZuCCA, supra note 263, at 179-80. Zucca claims there that the juridical domain has primacy; when religious groups clash, the only possible way to solve the conflict is through secular laws; because they cannot compromise on their tents of faith. And, when scientists clash about diverging scientific paradigms, they resort to quasi-juridical forms in order to establish which version is authoritative. Id. Similarly, the juridical domain is necessary to solve conflicts between religious and natural laws. Id.

349. ZuCCA, supra note 263, at 178-82.

350. See generally Hans Kelsen, Pure Theory of Law (Max Knight trans., 2003); Hans Kelsen, Secular Religion (Robert Walter, Clemens Jabloner \& Klaus Zeleny eds., 2011) (arguing against the rise of theology in the West). 
experience." ${ }^{351}$ But constitutional eternity seeks to impose an unchangeable principle on society. It allegedly leaves no place for disagreement or deliberations. For example, the Turkish absolute entrenchment of secularism in Article 4 prohibits even proposing amendments to the characteristics of the Republic thereby placing the bar at a very early stage. ${ }^{352}$

András Sajó recently claimed that certain fundamental demands of constitutionalism require secularism. "W53 "When constitutional law insists on secularism," Sajó claims, "it insists on the possibility of a reason-based political society. . . . The secular constitutional state is presupposed to exist as a political community of citizens exercising their rational faculties." ${ }^{354}$ Without the requirement of public reason, which requires the citizens to think critically, democracy is meaningless. ${ }^{355} \mathrm{I}$ have no intentions in challenging Sajó's strong and, to my mind, compelling normative claim. My aim is much less ambitious as I merely wish to point to a certain paradox of shielding secularism in a supposedly eternal manner.

As Sajó himself recognizes, a historical inter-connection exists between secularism and popular sovereignty. Secularism emerged as a denial of the divine power of the king as a sovereign, in favor of popular sovereignty. Popular sovereignty means that all power in the state originates from the people (thus it cannot originate from the sacred): "[P]opular sovereignty emanates from individuals; it exists as the aggregate of individual choices, and such autonomous individual choices serve as the foundation of democratic society." 356

But constitutional unamendability allegedly blocks popular sovereignty as it places certain principles above everyday ordinary

351. David Dyzenhaus, Legitimacy of Legality, 46 U. Toronto L.J. 129, 167 (1996).

352. See supra note 29 and accompanying text.

353. Sajó, supra note 249 , at 67.

354. Id. at 70; see also Sajó, supra note 33, at 2401 ("Constitutionalism exists only where political powers do not ground their public affecting decisions on transcendental concerns.").

355. Sajó, supra note 249 , at 74 . For Sajó, robust secularism that would not allow privileged religious knowledge to dictate public decisions does not mean that such positions cannot be held and represented in the public sphere. Id. Thus, when it comes to public discourse, such as legislative decision-making, religious people are free to make arguments in public. $I d$.

356. Id. at 75; see also id. at 605 . On the origins of popular sovereignty, see Daniel Lee, Popular Sovereignty in Early Modern Constitutional Thought (2016). 
and even constitutional politics. It is therefore in clear tension with democracy. ${ }^{357}$ As Nadia Urbinati claimed, "Democracy's procedures of decision-making presume a permanent legal changeability because they assume that citizen's opinions are the core of political legitimacy." ${ }^{358}$ According to Urbinati, what makes a society democratic and secular is the permanent tension between the civil and religious, a tension that is neither repressed nor resolved once and for all. ${ }^{359}$ Constitutional unamendability is the strongest form of constitutionalism as it blocks democratic avenues for change and rejects majoritarian democrats. In that respect, Nimer Sultany is correct in his observation that secularists prioritize constitutionalism over democracy in the sense that they reject simple-majoritarian democracy as a justification for applying religious law, even at the cost of ignoring popular will. ${ }^{360}$ Of course, the same paradox of constitutional democracy exists even when the constitution protects the principle of democracy itself from change. It limits democracy in order to protect democracy. This is why I have argued that unamendability should be viewed as a tool averting the possibility of democracy's self-destruction rather than as an undemocratic mechanism. ${ }^{361}$ Indeed, when unamendable or eternity provisions protect democracy, "[T]heir basic underlying idea is that of a 'militant democracy' - evincing the fear that unfettered democracy

357. See, e.g., Melissa Schwartzberg, Democracy and Legal Change 2 (2009) (claiming that entrenchment "betrays one of democracy's most attractive legacies: the ability to modify law"); Richard Albert, Counterconstitutionalism, 31 DALhousie L.J. 1, 47-48 (2008) (arguing that unamendability undermines the basic promise of democratic constitutionalism since it restricts the constitutional possibilities open to the people governed by the Constitution); Richard Albert, Constitutional Handcuffs, 42 ARIZ. ST. L.J. 663, 667 (2010) ("deny citizens the democratic right to amend their own constitution and in so doing divest them for the basic sovereign rights of popular choice and continuing self-definition"). For a summary of the challenges to constitutional unamendability and a reply see Yaniv Roznai, Necrocracy or Democracy? Assessing Objections to Constitutional Unamendability, in AN UNCONSTITUTIONAL CONSTITUTION? UNAMENDABILITY IN CONSTITUTIONAL Democracies, supra note 2.

358. Nadia Urbinati, The Context of Secularism: A Critical Appraisal of the Post-Secular Argument, in Constitutional Secularism in an Age of Religious ReVIVAL 20, supra note 70.

359. Id. at 20-21.

360. Nimer Sultany, Against Conceptualism: Islamic Law, Democracy, and Constitutionalism in the Aftermath of the Arab Spring, 31 B.U. INT'L L.J. 435, 451 (2013).

361. RoZNAI, supra note 11, at 191. 
will allow its own destruction." 362 They reflect some kind of what I term "Amendophobia": the fear that the amendment provision would be abused to abrogate the core values of society. ${ }^{363}$ "Militant democracy," Tyulkina claims, "is a useful, practical tool to guard constitutionally recognized principles, including even the principle of secularism; however, it cannot be used as justification to stifle debate on the role of religion and the relationship between state and religious groups indefinitely." 364 Indeed, the deeper paradox I wish to emphasize exists when unamendability is used to shield the principle of secularism.

"Secularism," writes Domenic Marbaniang, "shifts the focus from religion to other 'temporal' and 'this-worldly' things, striving to change the present for a better and brighter future." ${ }^{365}$ In fact, the word secularism is derived from the Latin word saeculum, meaning a generation or this age. The Latin form saecularis means "worldly." 366 The idea of "this age" or "generation" goes counter to the constitutional idea of unamendability or eternity that is supratemporal and cross-generational. The principle of secularism is interconnected with the idea of temporality, as the secular concept itself was developed through the division of knowledge to "upper story," which belongs to theology and the "lower story," which belongs to philosophy and the temporal. ${ }^{367}$ Secularism rejects the sacred and transcendent worldview. ${ }^{368}$ If secularism rejects the sacred, how then can it claim for eternity?

Surely, the mechanism of constitutional unamendability or eternity is completely logical when a religious state protects core religious laws or principles because, as reviewed above, the core religious laws are considered eternal. For example, Iran's "Supplementary Fundamental Laws" of 1907 specified that Article 2, stating generally that laws must never be contrary to the sacred

362. Roznai, supra note 8, at 811. On "militant democracy" see the classical study: Karl Loewenstein, Militant Democracy and Fundamental Rights I, II, 31 AM. POL. SCI. REV. 417, 638 (1937). For contemporary debates, see, e.g., ANDRÁS SAJÓ, Militant Democracy (András Sajó ed., 2004); The 'Militant Democracy' Principle in Modern Democracies (Markus Thiel ed., 2009); Gregory H. Fox \& Georg Nolte, Intolerant Democracies, 36 HARV. InT'L L.J. 1 (1995).

363. Roznai, supra note 8 , at 776.

364. TYULKINA, supra note 81 , at 181.

365. MARBANIANG, supra note 59, at 1.

366. Id. at 3 .

367. Id.

368. Marbaniang, supra note 59, at 5 (citing John Desrochers, 2 The INDIA WE WANT TO BUILD 368 (1995)). 
precepts of Islam, "shall continue unchanged until the appearance of His Holiness the Proof of the Age (may God hasten his glad Advent!), ${ }^{369}$ thus requiring the intervention of a super-human factor, namely the advent of the Twelfth Imam, in order to allow its amendment. Indeed, a state's religious character is often expressly protected from amendments. ${ }^{370}$ Others do so implicitly. Like the implicit protection of secularism in India, in Pakistan, it was declared by the Supreme Court that Pakistan's Constitution has salient features - "Federalism[,] . . . [p]arliamentary [f]orm of Government blended with Islamic provisions" - that are beyond the amendment power. ${ }^{371}$

True, the core of religious thinking is considered unchangeable. But since the medieval times, we moved to the periods of enlightenment, rationality, modern constitution-making based upon the notion of popular sovereignty, and democratic deliberative mechanisms of decision-making. A revisit to the Turkish Constitutional Court's decision, which invalidated constitutional amendments in the headscarf decision for protecting the principle of secularism, could be useful. The Constitutional Court states that:

The secularism principle which has its intellectual origins in the Age of Renaissance, Reformation, and Enlightenment, is a common value of contemporary democracies. According to this principle, political and legal structures rely on the national choices that are a product of participatory democratic processes based on rationalism and scientific methodology. . . . Legal arrangements based on religious orders, rather than the national will that arises within a participatory democratic process, make individual liberty and the democratic process arising from such liberty impossible. ... Thus, contemporary democracies deny claims about an absolute reality, stand with rationalism against dogmas and prevent religion from

369. Helen Miller Davis, Constitutions, Electoral Laws, Treaties of States IN THE NeAR AND Middle EAST 118 (1953).

370. For example, many Arabic and Muslim states expressly protect Islam as the state's religion from any revisions. See The Constitution of AfGHAnistan Jan. 26, 2004, art. 149; Constitution of the People's Democratic Republic of Algeria 1989, art. 178; Constitution of the State of Bahrain May 26, 1973, arts. 2, 6; QANUNI ASSAASSI IRAN [IRANIAN CONSTITUTION] 1906, art. 2 QANUNI

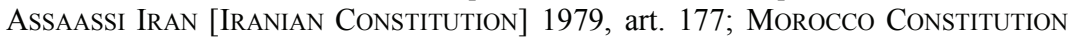
2011, art. 175 .

371. Achakzai v. Fede'n of Pakistan, (1997) 1997 PLD (SC) 426 (Pak.); see, e.g., Martin Lau, The Role of Islam in the Legal System of Pakistan 81-88 (2006). 
becoming politicized and an instrument of governance by separating religious and governmental affairs. ${ }^{372}$

And here lies the paradox. If modern constitutionalism in liberal democracies is indeed based on the "national choices that are a product of participatory democratic processes" and truly "deny claims about an absolute reality," then should not the method of constitutional unamendability or eternity of secularism itself be objected?

Secularism, Harvey Cox claims, "[F]unctions very much like a new religion." ${ }^{373}$ This is apparent with the mechanism of constitutional eternity. But protecting secularism through an eternal protection is paradoxical since, in a Schmittian political theology manner, it is a secularization of religious rationales - the existence of absolute truth that carries an immutable form. ${ }^{374}$ As Gottfried Dietze describes it, providing in the constitution that certain principles are immune from legal change is the transmutation of natural law ideas to positive law. ${ }^{375}$

Of course, the power of eternity in religions derives from a supra-human divine source. For example, in the case of God's law and the entrenchment in Deuteronomy 13, there is not prima facie difficulty; Man should not be able to deviate from the commandments of God. As Oren Gross correctly writes, "[T]he notion of amendment . . . becomes unbearable when the author of the constitution is . . . truly divine. . . . Thus, a theory of constitutional amendment which expressly exists in secular constitutional regimes,

372. See Roznai \& Yolcu, supra note 82, at 187 (citing Headscarf Decision of 2008, supra note 94, at 139).

373. Hans Schwarz, Method AND CONTEXT AS Problems FOR Contemporary Theology: Doing Theology in AN Alien World 49 (1991) (citing Harvey Cox, The Secular City-Secularism and Urbanization in Theological Perspective 21 (1965)).

374. See Carl Schmitt, Political Theology-Four New Chapters on The CONCEPT OF SOVEREIGNTY 36 (George Schwab trans. 2005).

All significant concepts of the modern theory of the state are secularized theological concepts not only because of their historical development-in which they were transferred from theology to the theory of the state, whereby, for example, the omnipotent God became the omnipotent lawgiver-but also because of their systematic structure, the recognition of which is necessary for a sociological consideration of these concepts.

Id. On Schmitt's political theology see, e.g., CARLO GALli, JanuS's Gaze: EsSAYS on CARl Schmitt (Adam Sitze ed., Amanda Minervini trans., Duke Univ. Press 2015).

375. Gottfried Dietze, Natural Law in the Modern European Constitutions, 1 NAT. L.F. 73, 77 (1956). 
including those that profess constitutional faith, has no room, as such, in '[m]ost major Western religions.' Human beings, no matter how wise, cannot amend divine law." ${ }^{376}$ However, the case of constitutional unamendability is different. The authority of the eternal principle of, for example, republicanism in France or secularism in Turkey, is the same as the authority of the constitutional norm making it "eternal"; both derive from a human source-the constitutional author representing the people. ${ }^{377}$ Constitutional eternity goes against modern constitution-making thinking, building upon the national free will of "we the people," which is considered as sovereign. ${ }^{378}$ Of course, constitutional eternity is selective. It demonstrates what Dietze describes as a nominalistic recognition of natural law by constituent power: "[O]nly what is recognized by the pouvoir constituant as natural law is natural law!" 379

As Copernicus affected a scientific revolution that shifted humanity from its central position in the universe, ${ }^{380}$ enlightened thinkers affected an intellectual revolution that sought to establish the human mind as the pivotal point in the universe. Since the enlightenment we have seen both the emergence of the "individual" and the growth of political theories based on the rational, liberal, and law-observing individual. This brings us to the paradox of constitutional unamendability. We include in the constitution certain unamendable safeguards that would ensure that the people act in a rational manner. This, for example, is one of the aims of the unamendable protection of secularism, as we learned from the jurisprudence of the Turkish Constitutional Court. But if individuals are indeed rational and responsible, then why do we need these safeguards in the first place? Therefore, the picture that we get, as

376. Oren Gross, Venerate, Amend . . . and Violate, 46 ARIZ. ST. L.J. 1151, 1155 (2014).

377. Weiler, supra note 266, at 8-10.

378. See the famous phrase by Abbé Sieyès: "The nation exists prior to everything; it is the origin of everything. Its will is always legal. It is the law itself." See Emmanuel-Joseph Sieyès, What Is the Third Estate?, in EMmanUEL-JoSEPH Sieyès, Political Writings 136 (Michael Sonencher ed. \& trans., 2003). Of course, even for Sieyès, the national will was limited in a way or conditioned by his conception of natural law: "Prior to the nation and above the nation, there is only natural law." Id. On the "rise of absolutism" with the rise of the secular political realm and in the revolutionary constitution-making era see HANNAH ARENDT, ON REVOLUTION 145-56 (1977).

379. Dietze, supra note 375 , at 88.

380. See, e.g., Edward Rosen, COPERnicus ANd His SuCCESSORS (1995). 
Loughlin correctly writes, is of an individual who "appears simultaneously as equal and unequal, rational and irrational, responsible and irresponsible." ${ }^{381}$

In order to understand the paradoxical move, we need to return to Plato's "noble lie." Plato was the first political thinker who sought a decisive break from the mythical worldview and aimed to construct a coherent political theory empty of Gods and spirits: "we are not writing stories . . . but founding a state," he wrote. ${ }^{382}$ In The Republic, he suggested an ideal state in which a very small fraction of the citizens will be Philosopher-Rulers who make the key policy decisions; another minority group would be the Auxiliaries, who enforce these decisions; and the majority of people do not participate in the government but focus on the business of everyday life. This social hierarchy is founded on an aristocracy of talent. This system would be justified by some "magnificent myth" or "noble lie" that would convince the entire community, and which is based on the following tale: "When God fashioned you, he added gold in the composition of those of you who are qualified to be Rulers . . ; he put silver in the Auxiliaries, and iron and bronze in the farmers and the rest. . . . [S]ince there is a prophecy that the State will be ruined when it has Guardians of silver or bronze," it is a basic duty of the Guardians to exercise care to ensure that children are allocated to rank in accordance with their character. ${ }^{383}$ Therefore, instead of eliminating myth from the realm of politics, Plato simply sought to replace "the stories in Homer and Hesiod and the poets" with new tales: "Our first business is to supervise the production of stories, and choose only those we think are suitable." ${ }^{84}$ This "noble lie" represents the civil religion of the just state. ${ }^{385}$

A similar process has been at work in the modern era. As JeanPierre Sironneau describes it, the concept of "the sacred," originating in ancient societies and in religious laws, was supposedly contradicted in the modern processes and era of secularization in modernity. Yet, it had not disappeared but reappeared in new areas

381. LoughLIN, supra note 309 , at 25.

382. Loughlin, supra note 309, at 24-25 (citing Plato, The Republic 379 (B. Jowett trans., Penguin Books 1955) (c. 380 B.C.E.)).

383. LOUGHLIN, supra note 309, at 24-25.

384. Id.

385. Benjamine Bilski, Plato's Political Ontology: On the Nature of Man and Regime, in RELIGION, PoliCy \& LAW 31, 54 (Bart C. Labuschagne \& Reinhard W. Sonnenschmidt eds., 2009). 
of human activity, most notably in the political sphere. ${ }^{386}$ Thus with the modern democratic constitution-making age, the ancient theological constituent power was transferred from the royal castle to the popular sovereign vested in the constitution. ${ }^{387}$ Just as religion cannot stand without a retrospective myth of the creation, the modern constitution requires an original constituent power that binds future derived powers, inter alia, through the use of eternity clauses. ${ }^{388}$ But as Howard McBain observed in his The Living Constitution, "The constitution ... was not handed down on Mount Sinai by the Lord God of Hosts. It is not revealed law . . . It is human means." ${ }^{389}$ As a product of human design, the constitution should be regarded as changeable, not as a document forever-Chukat Olam, like the Torah.

\section{CONCLUSION}

To conclude, at a first glance it appears that secularism is a non-negotiable principle in states where it is protected in the constitution as an eternal principle, above constitutional amending powers.

However, a deeper examination, as conducted with the case studies of Turkey, Tajikistan, and Mali, proves otherwise. Notwithstanding its prima facie eternal character, the principle of secularism remains negotiable in light of the elastic and vague nature of the principle. Especially in an increasingly religious society, where the constitutional unamendability of secularism goes against the Volksgeist, even constitutional eternity would not be able to hinder for long true forces in society. As Ernst-Wolfgang Böckenförde wrote:

[The State] is not a place as an entity that is fixed once and for all, and is not independent of individuals and their willingness to integrate into and commit to the state. As a unifying actor, the state requires continuous

386. Jean-Pierre Sironneau, Sécularisation et Religions Politiques 6 (1982) (Fr.).

387. Yoash Meisler, Constitutionalicist Theopathology 11 (2014) (Heb.)

388. Id. at 23 .

389. Howard Lee McBain, The Living Constitution: A Consideration OF the REALities AND LEgENDS OF OUR Fundamental LAW 272 (1927); see also Suzanne Last Stone, In Pursuit of the Counter-Text: The Turn to the Jewish Legal Model in Contemporary American Legal Theory, 106 HARV. L. REV. 813, 894 (1993) ("The Constitution . . . is a political document. It may even be a nomos . . . But it will not be Torah."). 
affirmation and reproduction in and through the actions of the humans who constitute it. ${ }^{390}$

The idea of a fixed notion once and for all is common in religious thinking. A religion is fundamentalist if it takes its own truth as absolute, leaving no room for compromise. But what about an absolute constitutional entrenchment, which blocks any constitutional or democratic avenues for its change? By leaving no room for disagreement, constitutional unamendability, even of secularism, is fundamentalist in a way. ${ }^{391}$

And here lies a paradox: If one focuses on the question of constitutional eternity, one cannot but be surprised at the fact that secularism has, in many contemporary societies, been enshrined as an eternal constitutional principle. After all, secularism belongs to the realm of immanence, not transcendence. ${ }^{392}$ The notion of something transcendental or eternal conflicts with the idea of immanence; therefore the constitutional eternity or unamendability of secularism creates an inner contradiction. Indeed, Lacabanne is correct in his description, that while secularism was meant to be a response to a religious society, and place the idea of the supremacy of progress, advancement, and change over immutable principles of a time that was considered to have passed, constitution-makers-like others before them-wanted to make other concepts and ideas eternal. Thus, secularism seems to have replaced religion in the definition that Ernest Renan attributed to God-“eternal and immutable, without progress or becoming." ${ }^{393}$

390. Ernst-Wolfgang Böckenförde, The Concept and Problems and the Constitutional State [1997], in Constitutional AND Political TheorySelected Writings 141, 149 (Mirjam Künkler \& Tine Stein eds., 2017). This is not to deny Böckenförde's acceptance, in a way, of the mere use of non-amendment clauses that realize the idea that the state competencies are not "the holders of the supreme all-encompassing power"; in the case of "eternity clauses" "the constitution itself, at its core legally inviolable, determines which political goals of the 'sovereign' are legitimate." Id. at 145.

391. See Jürgen Habermas, Struggles for Recognition in the Democratic State, in The Inclusion of the Other 224 (Ciaran P. Cronin \& Pablo de Greiff eds., 1998). As Jürgen Habermas describes it: "[F]undamentalist worldviews are dogmatic . . . they leave no room for reflection on their relationship with the other worldviews in which they share the same universe of discourse and against whose competing validity claims they can advance their positions on the basis of reasons. They leave no room for 'reasonable disagreement'." Id.

392. Rosenfeld, supra note 70 , at 82 .

393. See Lacabanne, supra note 147, at 9, referring to ERNEST RENAN, Philosophical Dialogues and Fragments 103 (1883). 
Aristotle made a distinction between natural justiceunchangeable, carries "the same validity everywhere, and does not depend on our accepting it or not," and the validity of positive or conventional justice, which depends on the act of human will choosing between different alternatives. ${ }^{394}$ The Gods may have an immutable natural justice, but men do not. For us humans, nature does not exclude the possibility of change. ${ }^{395}$

Modern constitutions are about understanding legal authority as a human creation formulated in a secular process and enabling such process to continue. ${ }^{396}$ In order to allow secular constitutions to continue their secular process, they must, in a way, perpetually protect secularism from being abolished. But then again, understanding modern constitutions as a human creation rejects any notion of eternity and emphasizes the changeable character of secular laws.

The strength of secularism (or any other constitutional claim for that matter) is dependent on the general acceptance of its values, through a complicated deliberative process that can establish political consensus, rather than seeking to demonstrate their eternal "truth." Again, I am not arguing here against the mechanism of constitutional eternity or the constitutional protection of secularism. I am merely describing its limited effectiveness in certain circumstances and pointing to the paradox that lies underneath it. At the very least, this Article affirms my previous claim that constitutional eternity should not be regarded as eternal but merely unamendable in the sense that it limits instituted constitutional amendment powers but not the people's primary constituent power. ${ }^{397}$

Like Plato's "noble lie" or tale, constitutional eternity is a myth. Constitutional eternity is similarly artificial — it is a symbolic production, formulated in order to create a certain modern political world.

394. Aristotle, The Nicomachean Ethics 126-27 (Wordsworth ed., Harris Rackham trans., 1996) (c. 350 B.C.E.). See generally M. Salomon, Le Droit Naturel chez Aristote, in 7 Archives de Philosophie Du Droit et De Sociologie JuridiQue 122-25 (1937) (Fr.).

395. ARISTOTLE, supra note 394, at 295. Even human nature, Aristotle believed, can change. Aristotle, Magna Moralia 24 (Clarendon Press 1954). "Things are just either by nature or by law. But we must not regard the natural as being something which cannot by any possibility change; for even the things which are by nature partake of change." Id.

396. Sajó, supra note 249, at 78.

397. See generally RozNAI, supra note 11. 